\title{
Removal of Typical Industrial Gaseous Pollutants: From Carbon, Zeolite, and Metal-organic Frameworks to Molecularly Imprinted Adsorbents
}

\author{
Yan Huang ${ }^{1}$, Wenhui $\mathrm{Su}^{1}$, Rui Wang ${ }^{1 *}$, Tiansheng Zhao ${ }^{2}$ \\ ${ }^{1}$ School of Environmental Science and Engineering, Shandong University, Jinan 250199, China \\ ${ }^{2}$ State Key Laboratory of High-Efficiency Utilization of Coal and Green Chemical Engineering, Ningxia University, \\ Yinchuan 750021, China
}

\begin{abstract}
In recent years, various adsorbents have been developed to alleviate atmospheric pollution and remove harmful gases, such as carbon dioxide, sulfur dioxide, nitrogen oxides, hydrogen sulfide and volatile organic compounds. Polymer-based adsorbents are a novel type of material now being used for gas separation and purification; in particular, molecular imprinted polymers (MIPs) can achieve selective adsorption of target gas molecules. However, existing review papers have not yet discussed the application of MIPs in gas purification. In this paper, therefore, we exhaustively summarize recently developed adsorbents, including the materials based on carbon, zeolite, and metal-organic frameworks as well as MIPs, to analyze the status of these materials and identify promising adsorbents for gas purification.
\end{abstract}

Keywords: Adsorption; Industrial gas; Molecule imprinting technique; Porous materials; Selectivity.

\section{INTRODUCTION}

Currently, $85 \%$ of demanded energy is supplied by thermal power plants that use fossil fuels (Akinyele et al., 2014). However, these processes generate a considerable amount of hazardous gases, such as carbon dioxide $\left(\mathrm{CO}_{2}\right)$, sulfur dioxide $\left(\mathrm{SO}_{2}\right)$, hydrogen sulfide $\left(\mathrm{H}_{2} \mathrm{~S}\right)$, nitrogen oxides $\left(\mathrm{NO}_{x}\right)$, and volatile organic compounds (VOCs). The methods of capturing $\mathrm{CO}_{2}$ can be categorized to precombustion and post-combustion capture (Jiang et al., 2019; Pai et al., 2019). Air pollution caused by $\mathrm{SO}_{2}$ has received considerable research attention recently because of its contributions in the forms of acid rain and secondary pollutants ( $\mathrm{Li}$ et al., 2018). $\mathrm{H}_{2} \mathrm{~S}$ is so toxic and corrosive that the U.S. Environmental Protection Agency (EPA) reported corrosion of concrete wastewater pipes (due to $\mathrm{H}_{2} \mathrm{~S}$ ) at a rate of $3.6 \mathrm{~m}^{2}$ year $^{-1}$, and of sewer pipes at a rate of 2.5-10 $\mathrm{m}^{2} \mathrm{a}^{-1}$ (Habeeb et al., 2017). $\mathrm{NO}_{x}$ has severe effects on the global ecosystem, particularly on human health. In addition, VOCs are the precursors of particles and ozone.

Therefore, separation and removal approaches, mainly adsorption and catalysis, have been developed to remove harmful gases. Among them, the adsorption method using

\footnotetext{
* Corresponding author.

Tel.: +86-531-88366367

E-mail address: wangrui@sdu.edu.cn
}

solid adsorbents as separation media has been widely used in processes such as airflow drying, hydrogen purification, and nitrogen and oxygen production (Sevilla and Fuertes, 2012; Huang and Wang, 2018; Pai et al., 2019). Traditional adsorbents have poor active sites, selectivity, and regeneration properties. Therefore, developing novel adsorbents with excellent properties is necessary for highly effective removal of these gases.

Molecular imprinting technique (MIT) is an interdisciplinary method that integrates polymer chemistry, materials science, chemical engineering and biochemistry. Molecularly imprinted polymers (MIPs) can be used to identify specific target molecules by mimicking the interaction between enzyme and substrates. According to the binding forms between templates and functional monomers, MIT can be categorized into covalent, noncovalent, and semicovalent methods. Covalent methods are also referred to as pre-organized methods, in which templates and functional monomers form precomplexes through covalent bonds (Shin et al., 2018). Noncovalent methods are also called self-assembly methods, in which templates and functional monomers form precomplexes through noncovalent bondsthrough hydrogen bonding, electrostatic attraction, charge transfer, ion-pair interactions, metal coordination, hydrophobic interactions, and van der Waals forces (Shin et al., 2018).

MIPs are a type of polymer material with a built-in recognition property that can be purposefully designed by changing templates, functional monomers, cross-linkers and initiators (Boysen, 2018). In other words, the polymerization 
processes of MIPs can be divided into three stages, as indicated in Fig. 1. First, prepolymers form between templates and functional monomers. They are subsequently chemically fixed by cross-linkers to create three-dimensional (3D) polymer networks. Finally, template molecules are removed from the polymers, thus producing specific cavities. MIPs have the advantages of simple preparation, high selectivity and easy regeneration because of a lot of active sites with spatial shapes and sizes similar to those of templates (Ying and Nan, 2010). They have been studied in a wide range of fields, such as adsorption, solid-phase extraction, catalysis, sensors, and electron probes (Cheong et al., 2013; Xu et al., 2019).

This study reviews advances in the development of absorbents for gas removal. Emphasis is placed on functional adsorbents, such as MIPs and carbon-based, zeolite-based, and metal-organic framework (MOF) materials, as well as their selectivity and separation properties.

\section{ADSORPTION AND CAPTURE OF COMMON GASES}

\section{Carbon Dioxide}

Major sources of $\mathrm{CO}_{2}$ are thermoelectric power plants and industrial plants, which account for approximately $45 \%$ of $\mathrm{CO}_{2}$ emissions (Lee and Park, 2015; Beidari et al., 2017). Many successful technologies have been developed and applied for $\mathrm{CO}_{2}$ capture, such as solvent absorption, chemical or physical adsorption, membrane separation, and cryogenic separation (Santiago et al., 2018). In addition, novel adsorbents have also been developed to reduce $\mathrm{CO}_{2}$ emissions, as indicated in Table 1. These adsorbents are capable of capturing and storing $\mathrm{CO}_{2}$ to directly reduce the
$\mathrm{CO}_{2}$ emissions from operational coal power plants (Tobiesen et al., 2018; Wawrzyńczak et al., 2019). Rezakazemi et al. (2019) conducted $\mathrm{CO}_{2}$ adsorption experiments using nanofluids in a gas-liquid hollow fiber membrane contactor and analyzed the results with a two-dimensional (2D) mathematical model. Simulation results revealed that the adsorption rate of $0.05 \mathrm{wt} \% \mathrm{SiO}_{2}$ nanoparticles increased to $16 \%$. However, using a $0.05 \mathrm{wt} \%$ carbon nanotubes (CNTs) increased the adsorption rate by up to $34 \%$. This result suggested that CNTs have markedly superior adsorption capacity and hydrophobicity compared with $\mathrm{SiO}_{2}$ nanoparticles. Louis et al. (2018) reported that membrane capacitive deionization (MCDI) could be used to capture $\mathrm{CO}_{2}$ as bicarbonate and carbonate ions produced by the reaction of $\mathrm{CO}_{2}$ and water at room temperature and atmospheric pressure. In this process without using chemicals, the absorption-desorption behavior of $\mathrm{CO}_{2}$ can be driven by the adsorption and desorption of bicarbonate ions from water.

\section{Activated Carbons}

Marszewska and Jaroniec (2017) prepared highlyporous carbon spheres by combining silica template and $\mathrm{CO}_{2}$ activation. The experimental results showed that mesoporosity could improve mass transfer, leading to high and fast $\mathrm{CO}_{2}$ adsorption, and the $\mathrm{CO}_{2}$ adsorption capacity reached $4.0 \mathrm{mmol} \mathrm{g}$ at $23^{\circ} \mathrm{C}$ and 1 bar. Ogungbenro et al. (2018) studied activated carbon synthesized from jujube seeds prevalent in the United Arab Emirates (UAE) for $\mathrm{CO}_{2}$ adsorption. The results suggested that the adsorbent with rich pores had high $\mathrm{CO}_{2}$ adsorption capacity of $141.14 \mathrm{mg} \mathrm{g}^{-1}$ at room temperature. Tehrani et al. (2019) prepared nitrogen-sulfur-doped nanoporous carbon with a

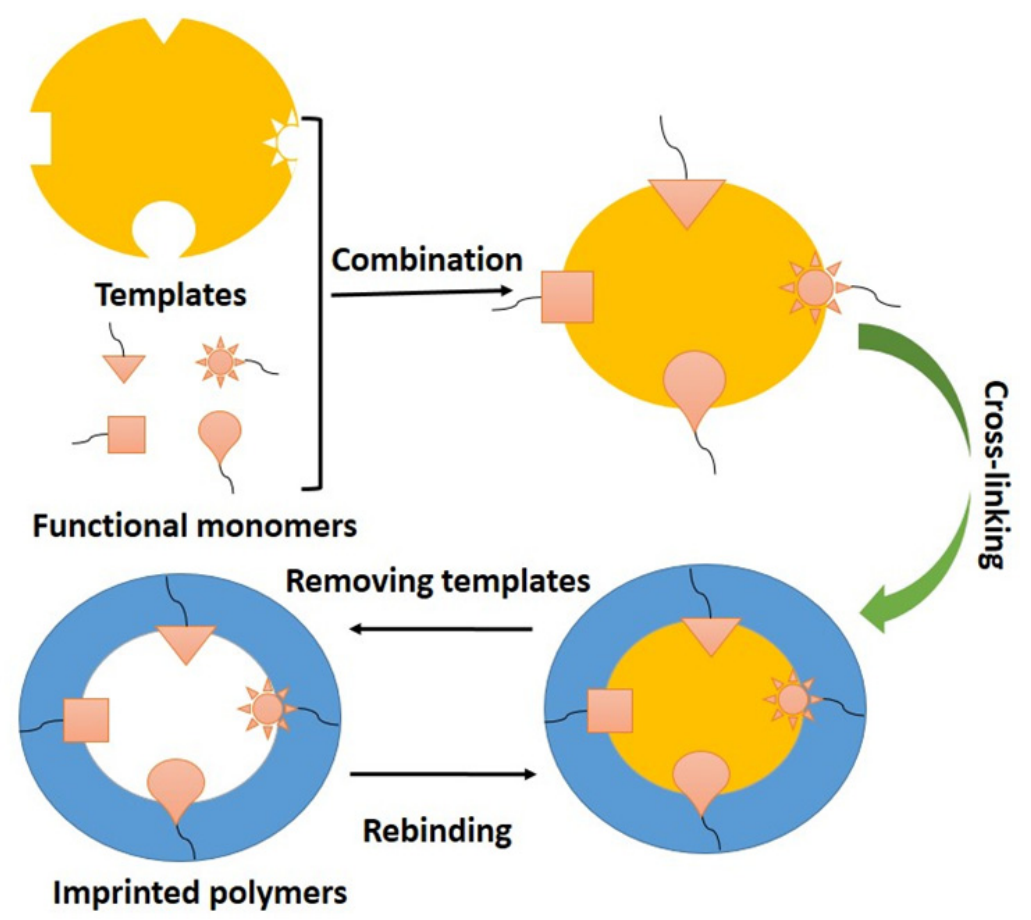

Fig. 1. Schematic of the preparation of imprinted polymers (Huang and Wang, 2018). 


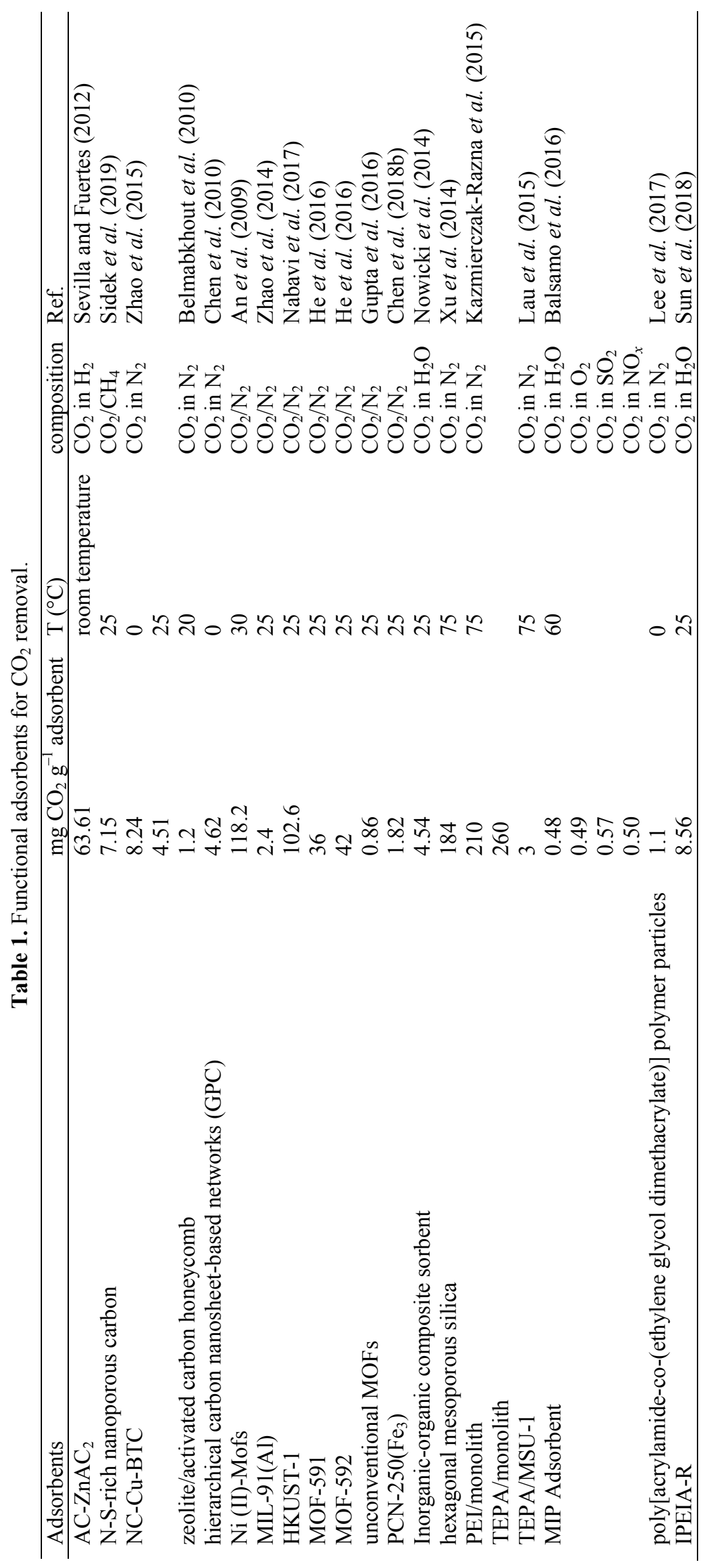


large surface area of $2186 \mathrm{~m}^{2} \mathrm{~g}^{-1}$ and pore volume of $1.3 \mathrm{~cm}^{3} \mathrm{~g}^{-1} \cdot \mathrm{CO}_{2}$ adsorption capacity reached $7.15 \mathrm{mmol} \mathrm{g}^{-1}$ at $1 \mathrm{bar}$ and $25^{\circ} \mathrm{C}$ and reached $29.29 \mathrm{mmol} \mathrm{g}^{-1}$ at $35 \mathrm{bar}$ and $25^{\circ} \mathrm{C}$, indicating that pressure significantly influenced $\mathrm{CO}_{2}$ absorption. Sidek et al. (2019) evaluated the $\mathrm{CO}_{2}$ adsorption performance of activated carbon (AC) impregnated by zinc acetate in terms of breakthrough time and adsorption capacity. The maximum $\mathrm{CO}_{2}$ adsorption capacity of the $\mathrm{AC}$ was $63.61 \mathrm{mg} \mathrm{g}^{-1}$, and the longest breakthrough time was $25.7 \mathrm{~min}$ under the optimum feed gas flow rate of $0.25 \mathrm{~L} \mathrm{~min}^{-1}$. Liu et al. (2019) designed novel composite adsorbents by combining a copper and benzene-1,3,5tricarboxylate(-BTC) framework with a series of porous carbons, including ordered mesoporous non-activated carbon (OMC), ordered mesoporous AC, and nitrogen-containing microporous carbon (NC), and used these adsorbents to capture $\mathrm{CO}_{2}$. Zhao et al. (2019) designed a new hybrid zeolite/AC honeycomb to achieve electrical swing adsorption for $\mathrm{CO}_{2}$. When the power-on time was extended from 30 to $180 \mathrm{~s}$, electrical swing adsorption achieved 15\%-34\% purity of $\mathrm{CO}_{2}$ products and $29 \%-78 \%$ recovery rate. In a vacuum and electrical swing adsorption process, however, the $\mathrm{CO}_{2}$ purity and recovery rate reached $33 \%$ and $72 \%$, respectively, under the conditions of $10 \mathrm{kPa}$ and electrochemical time of $<30$ s. Zhang et al. (2018) prepared nitrogen-doped activated carbon (AC-N) using melamine as the nitrogen source and studied its catalytic performance for $\mathrm{CO}_{2}$. The results revealed that $\mathrm{AC}-\mathrm{N}$ had $60 \%$ and $75 \%$ conversion rates for methane $\left(\mathrm{CH}_{4}\right)$ and $\mathrm{CO}_{2}$, respectively. Li et al. (2019) prepared $\mathrm{AC}$ from petroleum coke through the potassium hydroxide $(\mathrm{KOH})$ chemical activation method. The results indicated that $\mathrm{AC}$ had a high adsorption capacity of $\mathrm{CO}_{2}$ by volume. Different from the above adsorbents, Xie et al. (2017) studied the amine-modified carbon aerogel for $\mathrm{CO}_{2}$ capture, and found that the maximum adsorption capacity was $2.06 \mathrm{mmol} \mathrm{g}^{-1}$ when the amine loading of carbon aerogel was 55 wt.\%. Shao et al. (2018a) fabricated the porous carbon with the organic-inorganic hybrid framework thorough the direct carbonization and $\mathrm{KOH}$-activation carbonization of triazine-based hyper-cross-linked polymers. Under the optimum preparation conditions, the surface area could attain $2058 \mathrm{~m}^{2} \mathrm{~g}^{-1}$. At $298 \mathrm{~K}$ and 10 bar, the adsorption capacity of the adsorbent for $\mathrm{CO}_{2}$ was $590 \mathrm{mg} \mathrm{g}^{-1}$. The $\mathrm{CO}_{2} / \mathrm{N}_{2}$ selectivity experiment suggested the best Henry's law $\mathrm{S}_{\mathrm{CO} 2 / \mathrm{N} 2}$ was 16.1 . The result showed that the porous carbon with excellent surface area and microporosity structure had good adsorption and selectivity properties for $\mathrm{CO}_{2}$.

\section{Metal-organic Frameworks}

MOFs have been studied for laboratory-scale applications such as gas separation, purification, storage, and heterogeneous catalysis. Zhao et al. (2015) discovered that some MOFs have favorable $\mathrm{CO}_{2}$ capacity and high $\mathrm{CO}_{2}$ selectivity with regard to dinitride $\left(\mathrm{N}_{2}\right)$. Pai et al. (2019) prepared five MOFs modified by diamine and evaluated post-combustion $\mathrm{CO}_{2}$ capture from dry flue gas through a vacuum swing adsorption process. Among them, the mmen$\mathrm{Mn}_{2}$ (dobpdc) and mmen- $\mathrm{Mg}_{2}$ (dobpdc) resulted in $\mathrm{CO}_{2}$ purity and recovery of $95 \%$ and $90 \%$, respectively. In the presence of $\mathrm{N}_{2}$, these MOFs exhibited higher selectivity for $\mathrm{CO}_{2}$. Gholidoust et al. (2019) discovered that compared with other solid physical adsorbents, some MOFs had higher $\mathrm{CO}_{2}$ capture capacities under high pressure but poorer capacities at low $\mathrm{CO}_{2}$ partial pressures. Elsabawy and Fallatah (2019) prepared an amorphous nickel-(II)-MOF with an ultrahigh BET surface area, and the maximum adsorption capacity was $118.2 \mathrm{mg} \mathrm{CO}_{2} \mathrm{~g}^{-1}$ under the conditions of $30^{\circ} \mathrm{C}$ and 27 bar. Kong et al. (2018) synthesized a stable layered bisphosphonate, MIL-91(Al), for adsorbing $\mathrm{CO}_{2}$ under various environmental conditions. The MIL-91(Al) exhibited a maximum adsorption capacity of $2.4 \mathrm{mmol} \mathrm{g}^{-1}$, and higher selectivity for $\mathrm{CO}_{2}$ than for $\mathrm{N}_{2}$ and $\mathrm{CH}_{4}$. Shalini et al. (2018) investigated the potential of MOFs to separate $\mathrm{CO}_{2}$ from industrial-rich greenhouse gas mixtures. Silva et al. (2018) synthesized a new type of microporous zirconate material using formaldehyde as the solvent. When evaluated on the basis of ideal adsorption solution, the results revealed that the material had higher selective adsorption capacity for $\mathrm{CO}_{2}$ than for $\mathrm{N}_{2}$ and $\mathrm{CH}_{4}$. Zhou et al. (2018b) modified the metal-organic skeleton (HKUST-1) by doping lithium to improve its $\mathrm{CO}_{2}$ adsorption performance; the modified HKUST-1 with a moderate concentration of lithium nitrate solution as the dopant demonstrated the best adsorption capacity for $\mathrm{CO}_{2}$. Nguyen et al. (2018) employed the solvothermal method to synthesize three new lanthanide MOFs, namely MOF-590, MOF-591, and MOF-592. Among them, MOF-590 exhibited best conversion efficiency (96\%), selectivity (95\%) and yield (91\%). MOF-591 and MOF592 had moderate $\mathrm{CO}_{2}$ adsorption capacities of 36 and $42 \mathrm{~cm}^{3} \mathrm{~g}^{-1}$, respectively, at 800 Torr and $298 \mathrm{~K}$.

\section{Composite Materials}

Amine-based chemical adsorption has been commercially used for $\mathrm{CO}_{2}$ separation in the natural gas industry (Rayer et al., 2018). Chen et al. (2009, 2010) synthesized a series of hexagonal mesoporous silica (HMS) materials with different textural porosities by using dodecylamine as a structure-directing agent and loaded polyethylenimine (PEI) on the surface of HMS to prepare PEI/HMS adsorbents for $\mathrm{CO}_{2}$ capture. They found that PEI/HMS adsorbents exhibited a $\mathrm{CO}_{2}$ capture capacity superior to that of other silica-supported amine sorbents and had adequate regeneration performance. Wang et al. (2011) proposed tetraethylenepentamine (TEPA)/MSU-1, which was prepared by incorporating TEPA with selfprepared mesoporous silica MSU-1 using cheap sodium silicate as the silica source; they discovered that the TEPA/MSU-1 has a high adsorption capacity for $\mathrm{CO}_{2}$. Lai et al. (2018) prepared an inorganic-organic composite solid sorbent by using aminoethylethanolamine to impregnate nanoporous silicic acid and thereby capture $\mathrm{CO}_{2}$ from flue gas. In another study, PEI was immobilized in a silica substrate to capture $\mathrm{CO}_{2}$ through a pressure swing adsorption process (An et al., 2009).

Recently, Zhao et al. (2014) synthesized molecularly imprinted $\mathrm{CO}_{2}$ adsorbents ( $\mathrm{CO}_{2}$-MIPs) by using ethanedioic acid, acrylamide, and ethylene glycol dimethacrylate as the template, functional monomer, and cross-linker, respectively. 
They investigated the $\mathrm{CO}_{2}$-MIPs' ability to separate $\mathrm{CO}_{2}$ from coal-fired flue gas after desulfurization; under the optimum adsorption temperature of $60^{\circ} \mathrm{C}$, the maximum adsorption capacity of $\mathrm{CO}_{2}$ was $0.57 \mathrm{mmol} \mathrm{g}^{-1}$. The researchers also prepared a series of $\mathrm{CO}_{2}$-MIPs by employing the molecular self-assembly method. They discovered that MIP1b with a high amine content demonstrated favorable $\mathrm{CO}_{2}$ capacity compared with MIP3 and remained stable after 50 adsorption-desorption cycles. In an atmosphere of $15 \%$ $\mathrm{CO}_{2}$ and $85 \% \mathrm{~N}_{2}$, the $\mathrm{CO}_{2}$ separation coefficients of all adsorbents were over 100 (Zhao et al., 2012). Nabavi et al. (2017) also synthesized $\mathrm{CO}_{2}$-MIPs in oil-in-oil emulsion through suspension polymerization. The $\mathrm{CO}_{2}$-MIPs had selectivity of $49 \%$ for $\mathrm{CO}_{2} / \mathrm{N}_{2}$ at 0.15 bar $\mathrm{CO}_{2}$ partial pressure, and of $97 \%$ at ultralow $\mathrm{CO}_{2}$ partial pressure. Liu et al. (2018b) synthesized molecularly imprinted solid amine adsorbents through a simple cross-linking reaction by using PEI as the framework, glycidyl ether as the crosslinker, and a $\mathrm{CO}_{2}$ molecule as the template. The synthesis process of the molecularly imprinted solid amine adsorbent is displayed in Fig. 2. The amine content of MIP-PEI reached $11.41 \mathrm{mmol} \mathrm{g}^{-1}$, but the diffusion resistance of $\mathrm{CO}_{2}$ was low during the $\mathrm{CO}_{2}$ adsorption process. The adsorption capacity of MIP-PEI for $\mathrm{CO}_{2}\left(6.58 \mathrm{mmol} \mathrm{g}{ }^{-1}\right)$ was higher than that of nonimprinted NIP-PEI $\left(5.87 \mathrm{mmol} \mathrm{g}^{-1}\right)$. Water significantly improved the adsorption capacity of $\mathrm{CO}_{2}$ by promoting the chemical adsorption of $\mathrm{CO}_{2}$ on solid amine adsorbents. He et al. (2016) prepared a $\mathrm{CO}_{2}$-imprinted solid amine adsorbent, and the adsorption results revealed that the imprinting of sodium borohydride $\left(\mathrm{NaBH}_{4}\right)$ on $\mathrm{CO}_{2}$ and the reduction of imino groups led the adsorbent to have a high adsorption capacity for $\mathrm{CO}_{2}$. The solid amine adsorbent based on PEI exhibited a remarkable $\mathrm{CO}_{2}$ adsorption capacity of $8.56 \mathrm{mmol} \mathrm{g}^{-1}$ in the presence of water at $25^{\circ} \mathrm{C}$, which was attributed to its high amine content and strong swelling performance. The regeneration experiment revealed that the $\mathrm{CO}_{2}$ adsorption capacity remained unchanged after 15 adsorption-desorption cycles, suggesting that the prepared adsorbents had adequate regeneration performance.

In the future, $\mathrm{CO}_{2}$ will be one of the most important energy sources because it has the potential to be converted into various value-added chemicals, such as methanol, formic acid, carbonates, and carboxylic acid (Yang and Wang, 2015). However, the concentration of $\mathrm{CO}_{2}$ in the industrial gases is too low and cannot meet the reaction requirement of catalytic conversion. Therefore, developing cheap and functional adsorbents with highly effective adsorption and catalytic properties is the key research direction to develop new and enabling processes. As a whole, new functional adsorbents, cheap and readily available, environment-friendly, selective and reusable, are desirable.

\section{Hydrogen Sulphide}

$\mathrm{H}_{2} \mathrm{~S}$, which is an odorous, poisonous, and corrosive gas, is found in many industrial fields, such as oil production, coal gasification, natural gas, digester gas, and metal smelting (Liu and Wang, 2017a). The use of $\mathrm{H}_{2} \mathrm{~S}$ not only hinders industrial production and leads to high running costs but also has considerable effects on human health, such as headaches, dyspnea, dizziness, and even asphyxiation, loss of consciousness, and fatality (Gupta et al., 2016). The Occupational Safety and Health Administration (OSHA) categorized $\mathrm{H}_{2} \mathrm{~S}$ concentrations into three levels of toxicity: $10 \mathrm{ppm}$ or less denotes low toxicity, between $10 \mathrm{ppm}$ and $30 \mathrm{ppm}$ is considered medium toxicity, higher than $30 \mathrm{ppm}$ is high toxicity for humans (OSHA, 2015). Therefore, the removal of $\mathrm{H}_{2} \mathrm{~S}$ would considerably influence industrial production, environmental quality and the occurrence of human health problems. In addition, raw industrial gases commonly contain $\mathrm{H}_{2} \mathrm{~S}, \mathrm{CO}_{2}, \mathrm{CH}_{4}$ and other light alkanes. Among the methods used to remove $\mathrm{H}_{2} \mathrm{~S}$, adsorption is regarded as one of the most suitable approaches because of the advantages of low running costs, low corrosion and

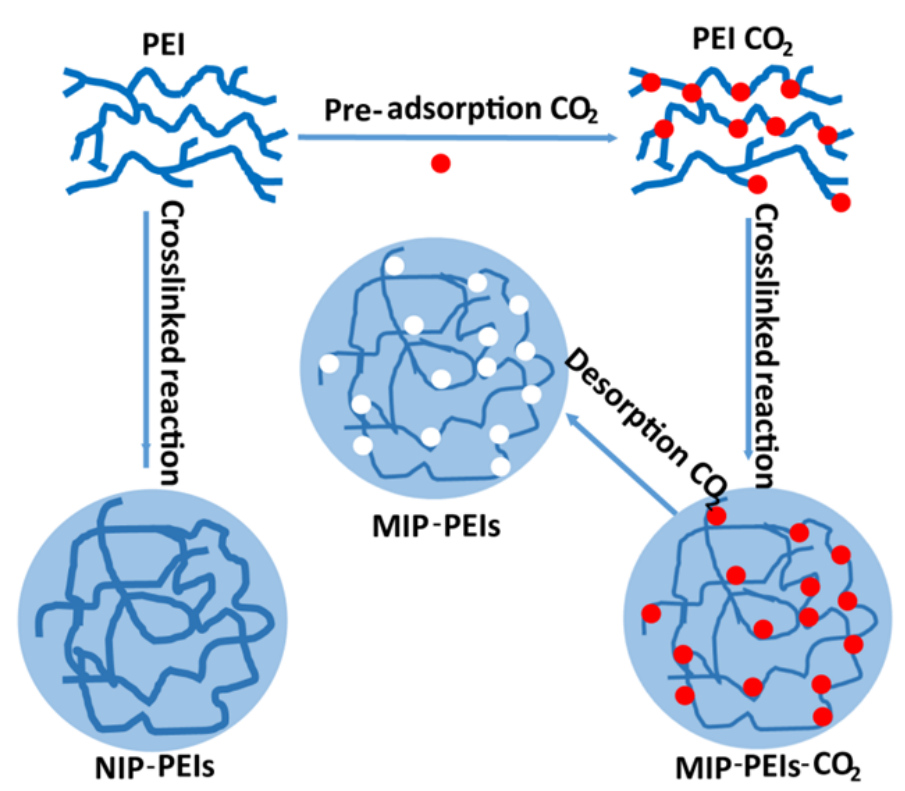

Fig. 2. The synthesis process of molecularly imprinted solid amine adsorbent (Liu et al., 2018). 
flexibility. In recent years, novel functional adsorbents have been widely studied for their ability to achieve $\mathrm{H}_{2} \mathrm{~S}$ selective separation and removal; as indicated in Table 2, these adsorbents include MOF-based, carbon-based, zeolitebased, metal oxide-based, and composite materials.

\section{Carbon-based Functional Materials}

AC with abundant pore channels is a well-known adsorption material that can be easily prepared through the carbonization of biomass such as wood, coconut shells and straw. Nowicki et al. (2014) prepared carbonaceous materials by using coffee industry waste and found that an appropriate amount of steam promoted $\mathrm{H}_{2} \mathrm{~S}$ adsorption. $\mathrm{Xu}$ et al. (2014) also proved that the introduction of steam increased the adsorption capacity of $\mathrm{AC}$ for $\mathrm{H}_{2} \mathrm{~S}$; the adsorption capacities of $\mathrm{AC}$ from sewage sludge and pig manure increased from 43.9 and 59.6 to 47.5 and $65.5 \mathrm{mg} \mathrm{g}^{-1}$, respectively, under a $25 \mathrm{wt} \%$ humidity. For safer and easier AC preparation, Kazmierczak-Razna et al. (2015) utilized sawdust pellets to synthesize AC through microwave radiation. However, the adsorption capacity of the prepared AC for $\mathrm{H}_{2} \mathrm{~S}$ was $6.2 \mathrm{mg} \mathrm{g}^{-1}$, which may be caused by its low surface area of $426 \mathrm{~m}^{2} \mathrm{~g}^{-1}$. Lau et al. (2015) prepared $\mathrm{AC}$ derived from palm shell by loading cerium oxide $\left(\mathrm{CeO}_{2}\right)$ and sodium hydroxide $(\mathrm{NaOH})$ to remove $\mathrm{H}_{2} \mathrm{~S}$ from biogas, and the adsorbent exhibited adequate removal capability for $\mathrm{H}_{2} \mathrm{~S}$ in the presence of $\mathrm{CO}_{2}$ and $\mathrm{CH}_{4}$. To enhance the interaction between the carbon surface and $\mathrm{H}_{2} \mathrm{~S}, \mathrm{Yu}$ et al. (2015) introduced $\mathrm{N}$ heteroatoms into the carbon matrix, thereby obtaining nitrogen-doped porous carbons (NPCs)

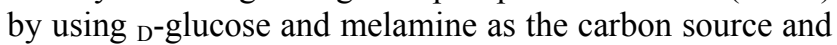
nitrogen source, respectively. The binding energy result demonstrated that the interaction between pyridinic $\mathrm{N}$ and $\mathrm{H}_{2} \mathrm{~S}\left(-14.6 \mathrm{~kJ} \mathrm{~mol}^{-1}\right)$ was greater than that at the raw carbon surface $\left(-1.8 \mathrm{~kJ} \mathrm{~mol}^{-1}\right)$. Fauteux-Lefebvre et al. (2015) prepared iron-functionalized carbon nanofilaments (Fe-CNFs) to study their removal ability for $\mathrm{H}_{2} \mathrm{~S}$ at low $\left(100^{\circ} \mathrm{C}\right)$ and high $\left(300^{\circ} \mathrm{C}\right)$ temperatures. The CNFs acted as not only a sulfur adsorbent but also the carrier for evenly dispersing the iron, which had two roles in the FeCNFs: at $100^{\circ} \mathrm{C}$, it enhanced the $\mathrm{H}_{2} \mathrm{~S}$ retention capacity of the CNFs, and at $300^{\circ} \mathrm{C}$, it reacted with $\mathrm{H}_{2} \mathrm{~S}$ to form iron sulfide. Balsamo et al. (2016) studied the $\mathrm{H}_{2} \mathrm{~S}$ removal property of $\mathrm{AC}$ loaded with $\mathrm{Zn}$ and $\mathrm{Cu}$ and demonstrated that functional $\mathrm{AC}$ had superior adsorption ability to that of raw AC. Temperature-programmed desorption of the saturated adsorbents revealed that a combination of $\mathrm{H}_{2} \mathrm{~S}$ adsorption and oxidation led to the formation of metal sulfates, thus exhibiting surface reaction complexity. Lee et al. (2017) used goethite $(\alpha-\mathrm{FeOOH})$ to modify AC for $\mathrm{H}_{2} \mathrm{~S}$ removal from a gas stream. The composite adsorbent had superior removal ability, which is because the introduction of $\mathrm{AC}$ as support prevented the agglomeration of $\alpha-\mathrm{FeOOH}$ and further increased the utilization rate of active sites. Goncalves et al. (2018) evaluated the $\mathrm{H}_{2} \mathrm{~S}$ adsorption capacities of ACs with different pore sizes from monocomponent $\mathrm{H}_{2} \mathrm{~S}$ and mixture gases of $\mathrm{H}_{2} \mathrm{~S}, \mathrm{CO}_{2}$ and $\mathrm{CH}_{4}$ and discovered that $\mathrm{CO}_{2}$ promoted $\mathrm{H}_{2} \mathrm{~S}$ adsorption in AC with $8.9 \AA$ pores. To achieve the effective regeneration of adsorbents, Farooq et al. (2018) applied a new regeneration method, electric potential swing desorption, for the regeneration of saturated $\mathrm{AC}$; this method resulted in $\mathrm{H}_{2} \mathrm{~S}$ desorption that was three times faster than that resulting from the nonpotential desorption method. In addition, structured carbons, including CNTs and graphenebased materials, are mainly applied in sensor research to detect $\mathrm{H}_{2} \mathrm{~S}$ (Asad and Sheikhi, 2014; Choi et al., 2014; Duong-Viet et al., 2016; Song et al., 2016; Chu et al., 2018; Liao et al., 2018).

\section{Zeolite-based Functional Materials}

As a type of porous crystalline material, zeolites have the advantages of high surface area and regular pore size and shape, which have led to their wide application in the fields of adsorption and catalysis. For desulfurization, zeolitebased materials are mainly used as adsorbents because of their high sulfur capacity, strong regeneration performance, and stable structure. Tomadakis et al. (2011) studied the $\mathrm{H}_{2} \mathrm{~S}$ separation properties of $4 \mathrm{~A}, 5 \mathrm{~A}$, and $13 \mathrm{X}$ molecular sieves from $\mathrm{CO}_{2}$ through pressure swing adsorption. They discovered that the fresh $13 \mathrm{X}$ sieves exhibited the highest separation factor (11.9) for $\mathrm{H}_{2} \mathrm{~S} / \mathrm{CO}_{2}$ compared with the 5A (5.4) and 4A (2) zeolites. Maghsoudi et al. (2013) first investigated the adsorption ability of pure silica chabazite (Si-CHA) for $\mathrm{H}_{2} \mathrm{~S}, \mathrm{CO}_{2}$ and $\mathrm{CH}_{4}$, reporting that the adsorption capacity in order was $\mathrm{H}_{2} \mathrm{~S}>\mathrm{CO}_{2}>\mathrm{CH}_{4}$ and that the $\mathrm{H}_{2} \mathrm{~S}$ capacity was $4 \mathrm{mmol} \mathrm{g}^{-1}$ at $25^{\circ} \mathrm{C}$ and 2 bar. Shah et al. (2015) investigated the separation of seven allsilica zeolite frameworks (CHA, DDR, FER, IFR, MFI, MOR and MWW) for $\mathrm{H}_{2} \mathrm{~S} / \mathrm{CH}_{4}$ through Gibbs ensemble Monte Carlo simulations. When the $\mathrm{H}_{2} \mathrm{~S}$ concentration was low, MOR exhibited the highest selectivity and the most favorable enthalpy of adsorption for $\mathrm{H}_{2} \mathrm{~S}$; this was attributed to the favorable interactions between $\mathrm{H}_{2} \mathrm{~S}$ and adsorbents in its smaller pores. However, MFI demonstrated the highest degree of selectivity for $\mathrm{H}_{2} \mathrm{~S}$ at a high $\mathrm{H}_{2} \mathrm{~S}$ concentration (Shah et al., 2015). To improve the $\mathrm{H}_{2} \mathrm{~S}$ removal capacity of zeolite, Liu et al. (2015a) prepared a material with the dual functions of adsorption and photocatalysis by combining zeolite with titanium dioxide $\left(\mathrm{TiO}_{2}\right)$. The adsorbent had selective removal ability for $\mathrm{H}_{2} \mathrm{~S}$ and could be effectively regenerated through calcination. Hao et al. (2016) also investigated the $\mathrm{H}_{2} \mathrm{~S}$ removal ability of $\mathrm{TiO}_{2}$-zeolite, and the material exhibited an excellent $\mathrm{H}_{2} \mathrm{~S}$ removal rate $(97 \%)$ and low $\mathrm{SO}_{2}$ selectivity (9.2\%). Sigot et al. (2016b) studied the regeneration property of $13 \mathrm{X}$ zeolite through thermal desorption and discovered that zeolite had poor desorption behavior at a lower temperature $\left(350^{\circ} \mathrm{C}\right)$ in an inert atmosphere. From an industrial perspective, Liu and Wang (2017b) used cheap attapulgite to synthesize a 4A molecular sieve from zeolite for $\mathrm{H}_{2} \mathrm{~S}$ removal. The experimental result indicated that the zeolite had a higher sulfur saturation capacity of $12.4 \mathrm{mg} \mathrm{g}^{-1}$ at $50^{\circ} \mathrm{C}$ compared with pure sieves, and the saturated $4 \mathrm{~A}$ zeolite could be effectively regenerated through $\mathrm{N}_{2}$ purging at $350^{\circ} \mathrm{C}$; moreover, the highest removal rate for $\mathrm{H}_{2} \mathrm{~S}$ could be maintained at $100 \%$ in every cycle experiment. Similarly, Abdullah et al. (2018) utilized local kaolin as the alumina and silica source 


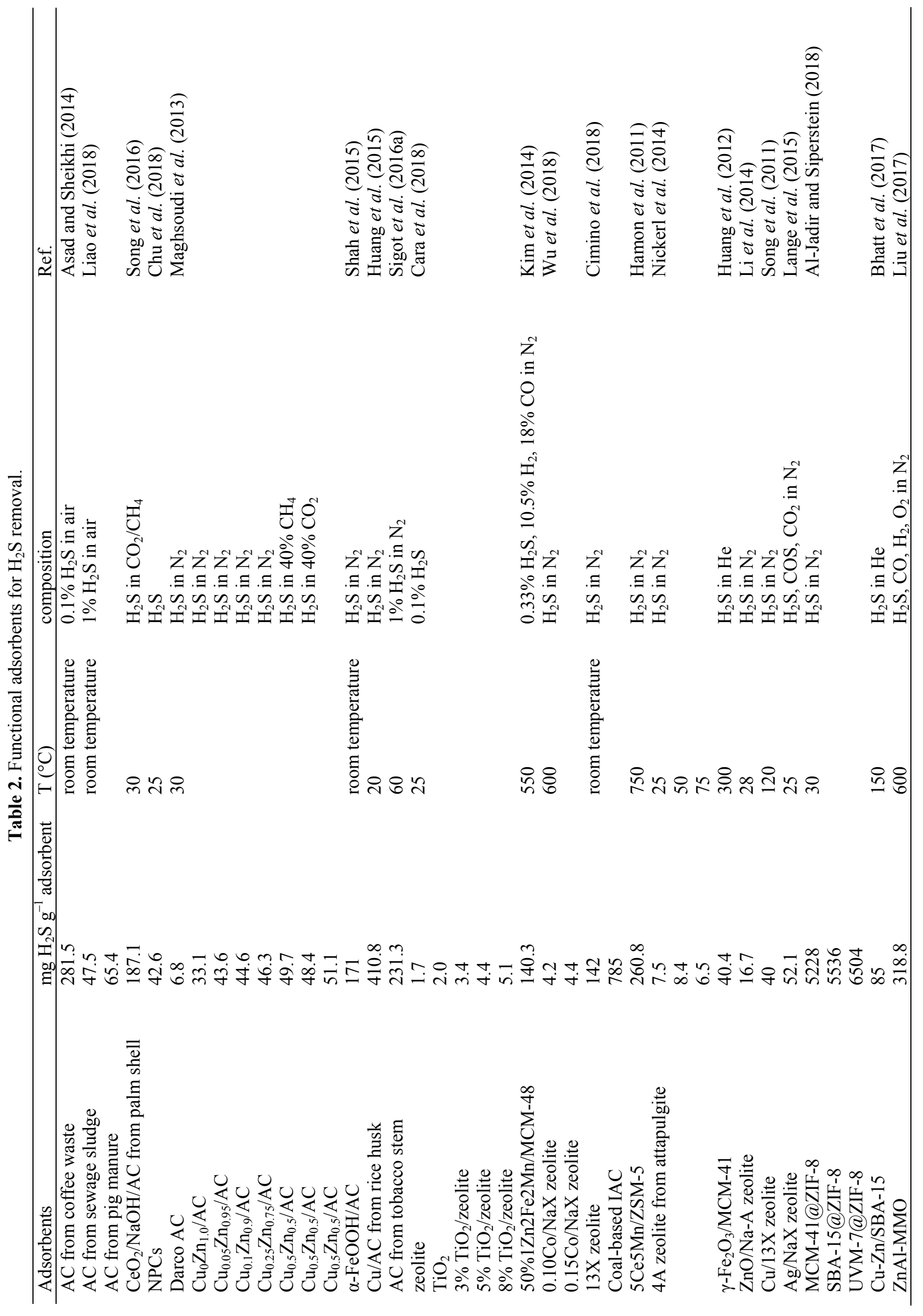




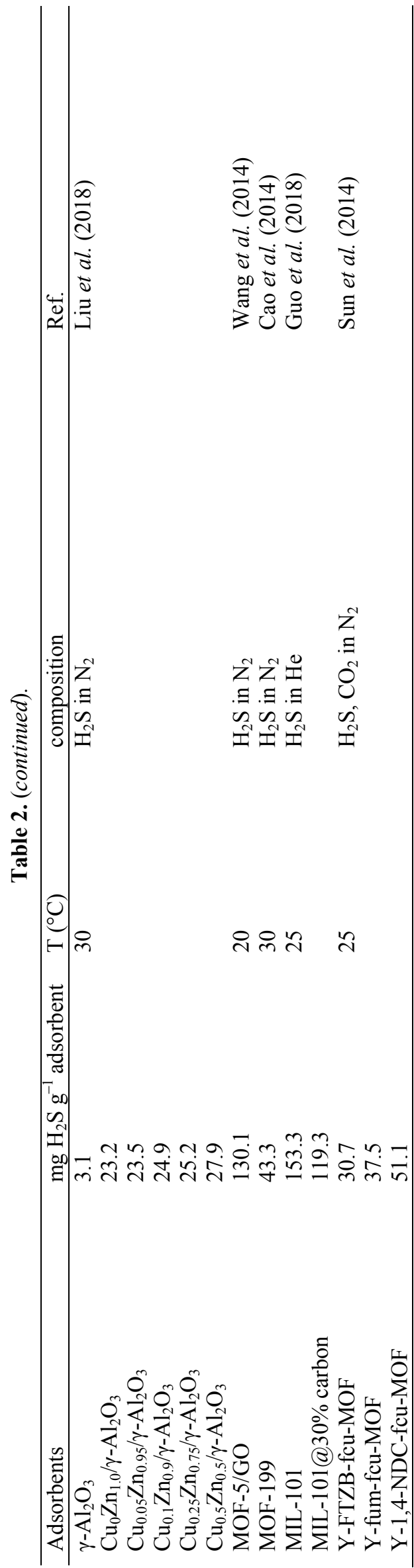

instead of pure chemicals to synthesize low-cost Na-A zeolite and then introduced zinc oxide $(\mathrm{ZnO})$ into its pore channels to remove $\mathrm{H}_{2} \mathrm{~S}$ from the biogas. On the basis of previous on $\mathrm{NaX}$ zeolite, Chen et al. (2018a) used $\mathrm{Zn}, \mathrm{Co}$, and $\mathrm{Ag}$ to modify $\mathrm{NaX}$ zeolite though the ion-exchange method; the NaX modified by Ag had the highest adsorption capacity for $\mathrm{H}_{2} \mathrm{~S}\left(1.53 \mathrm{mmol} \mathrm{g}^{-1}\right)$. Tran et al. (2016) also investigated Co-doped $\mathrm{NaX}$ zeolite. To study the effects of the pore structures and wall thickness of zeolites on $\mathrm{H}_{2} \mathrm{~S}$ removal, Cara et al. (2018) used maghemite $\left(\gamma-\mathrm{Fe}_{2} \mathrm{O}_{3}\right)$. modified hexagonal MCM-41 and cubic MCM-48. They discovered that the adsorbent based on hexagonal MCM-41 had more stable adsorption and superior regeneration performance compared with that based on cubic MCM-48.

\section{Metal Oxide-based Functional Materials}

In solid adsorbents for $\mathrm{H}_{2} \mathrm{~S}$ removal, the reaction temperatures of carbon-based materials are relatively low; nevertheless, the desulfurization process is discontinuous. Although their reaction temperatures are relatively high, metal oxides are the most widely used adsorbents in practical applications because of their high affinity for $\mathrm{H}_{2} \mathrm{~S}$. However, their disadvantages of low surface areas and lack of pores lead to poor regeneration and reutilization. To solve these problems, many scholars have studied the desulfurization performance of metal oxides loaded on solid matrices. Kim et al. (2014) prepared carbon nanofiber webs loaded with $\mathrm{ZnO}$ through electrospinning, as presented in Fig. 3; the webs demonstrated a desulfurization ability that was three times greater than that of pure $\mathrm{ZnO}$ adsorbent. Sun et al. (2014a) used ferric oxides to modify the surface of $\mathrm{AC}$ and reported that the sulfur saturation capacity reached $50.1 \%$. Wu et al. (2018) studied the $\mathrm{H}_{2} \mathrm{~S}$ removal property of a $\mathrm{Zn}$-Al mixed metal oxide ( $\mathrm{Zn}-\mathrm{Al}$ MMO) derived from layered double hydroxide in hot coal gas desulfurization. The adsorbent demonstrated an adequate sulfur capacity of $318.8 \mathrm{mg} \mathrm{g}^{-1}$, and X-ray photoelectron spectroscopy (XPS) indicated the production of elemental sulfur during the desulfurization process, as shown in Fig. 4. Cimino et al. (2018) dispersed $\mathrm{Zn}$ and $\mathrm{Cu}$ oxides onto $\gamma-\mathrm{Al}_{2} \mathrm{O}_{3}$ and studied the desulfurization ability at room temperature; their experiments revealed that $\mathrm{Cu}_{0.5} \mathrm{Zn}_{0.5} / \gamma-\mathrm{Al}_{2} \mathrm{O}_{3}$ had the best adsorption capacity $\left(27.9 \mathrm{mg} \mathrm{g}^{-1}\right.$ ) for $\mathrm{H}_{2} \mathrm{~S}$ under both dry and humid conditions.

\section{MOF-based Functional Materials}

MOFs are a type of porous crystalline materials consisting of a combination of organic ligands and metal ions or clusters. Because of their unique advantages of adjustable functionality, high porosity, and controllable composition, MOFs have attracted a considerable amount of attention in various fields, such as gas adsorption and catalysis. Hamon et al. (2011) compared the desulfurization performance of MIL-53(Cr) and MIL-47(V) at $30^{\circ} \mathrm{C}$ and discovered that the interactions of $\mathrm{H}_{2} \mathrm{~S}$ with both MIL-53(Cr) and MIL-47(V) were relatively weak and that the simulated adsorption enthalpies for $\mathrm{H}_{2} \mathrm{~S}$ were in decreasing order, MIL-53(Cr) (narrow pore) $>$ MIL-47(V) $>$ MIL-53(Cr) (large pore). Nickerl et al. (2014) investigated the $\mathrm{H}_{2} \mathrm{~S}$ removal ability 


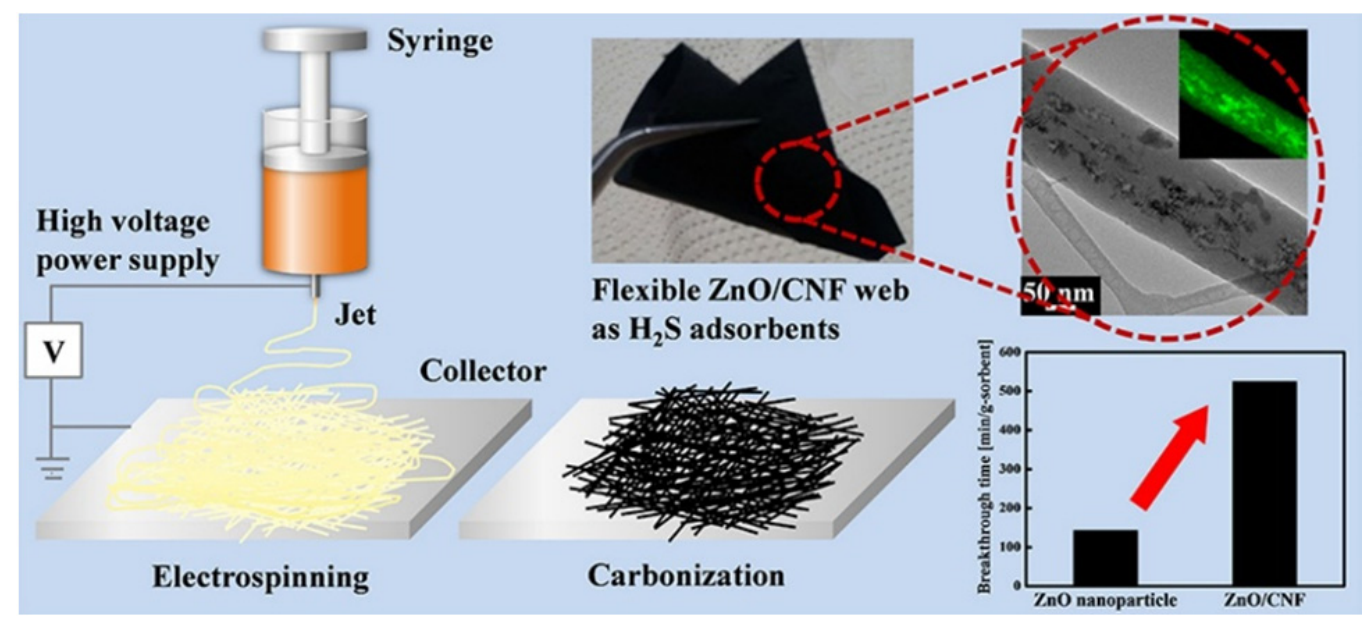

Fig. 3. A schematic of preparing $\mathrm{ZnO} /$ carbon nanofiber webs (Kim et al., 2014).

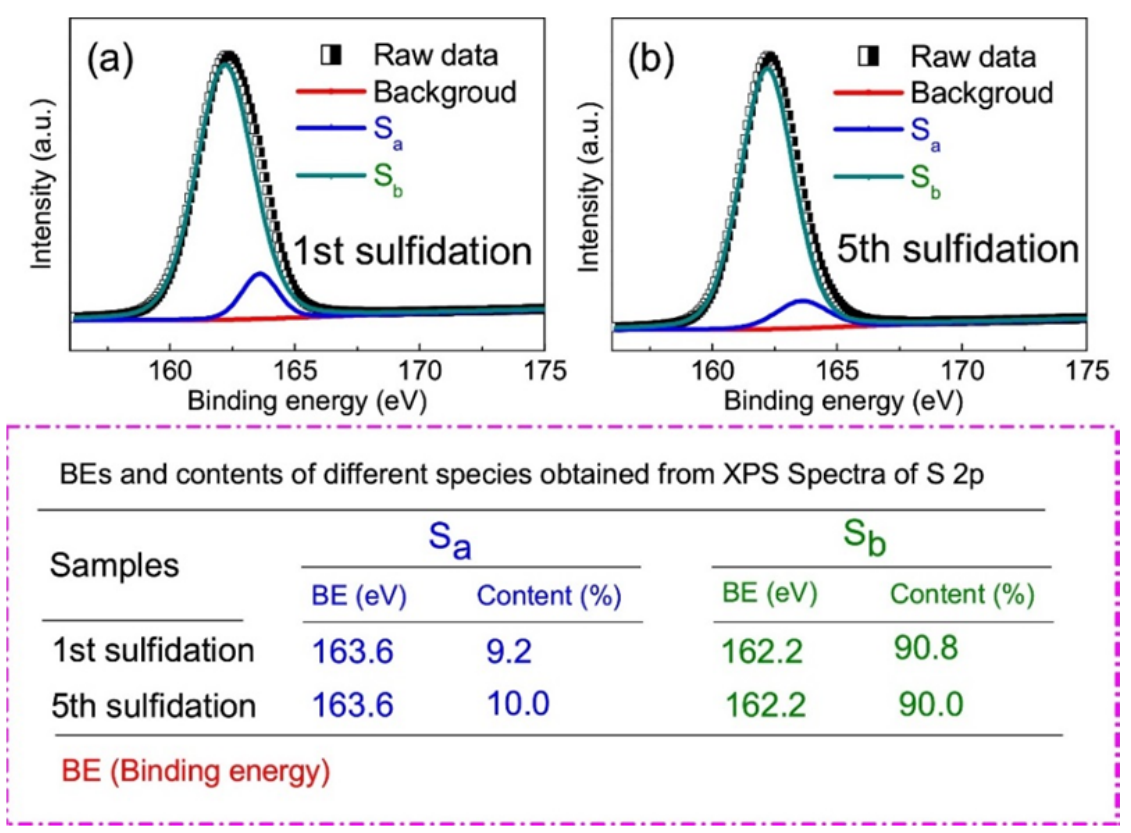

Fig. 4. Related results from S 2p XPS spectra of ZnAl-MMO (Wu et al., 2018).

of metal salts $\left(\mathrm{Cu}^{2+}, \mathrm{Ni}^{2+}\right.$ and $\left.\mathrm{Co}^{2+}\right)$ loaded on UiO-67; the adsorbent loaded with $86.8 \% \mathrm{Cu}\left(\mathrm{NO}_{3}\right)_{2}$ had the highest $\mathrm{H}_{2} \mathrm{~S}$ capacity (7.8 wt.\%). In addition, polyoxometalates (POMs) are widely used as catalysts in desulfurization because of their excellent redox ability. However, because pure POMs are solid materials and thus have low surface area, they do not exhibit ideal removal of $\mathrm{H}_{2} \mathrm{~S}$, because of a poor utilization rate of activated sites. Therefore, some scholars have attempted to combine MOFs with POMs, using MOFs as support to improve the desulfurization and regeneration of POMs. Song et al. (2011) investigated a material that combined a Keggin-type POM ([CuPW11O39 $]^{5-}$ ) with MOF-199 for $\mathrm{H}_{2} \mathrm{~S}$ removal. Solid octasulfur $\left(\mathrm{S}_{8}\right)$ was produced by using the composite, whereas pure MOF-199 did not produce $\mathrm{S}_{8}$. Lange et al. (2015) also investigated the removal performance of the aforementioned composite material for $\mathrm{H}_{2} \mathrm{~S}$ and methyl parathion at room temperature. Demir et al. (2017) evaluated the selective $\mathrm{H}_{2} \mathrm{~S}$ adsorption of functionalized UiO-66 with a series of functional groups through computational methods. Al-Jadir and Siperstein (2018) assessed the selective $\mathrm{H}_{2} \mathrm{~S} / \mathrm{CH}_{4}$ adsorption of UiO66 , UiO-67, and UiO-68 to study the effects of the pore sizes of MOFs on $\mathrm{H}_{2} \mathrm{~S}$ removal. The result revealed that linkers had no obvious influence on macroscopic properties at low pressures, but the differences among linkers increased at high pressures. Analysis of the selective adsorption parameter revealed that UiO-67 had the greatest potential for separating $\mathrm{H}_{2} \mathrm{~S}$ from natural gas. Sánchez-González et al. (2018) prepared Mg-CUK-1 using water as the solvent for $\mathrm{H}_{2} \mathrm{~S}$ and $\mathrm{CO}_{2}$ adsorption. An adsorption experiment demonstrated that the ecofriendly adsorbent could achieve reversible adsorption of $\mathrm{H}_{2} \mathrm{~S}$; a regeneration experiment revealed that the adsorption performance could be maintained after multiple cycles, and long-range crystallinity could be retained during the regeneration process. Liu et al. (2017) investigated the selective separation of 11 MOFs for $\mathrm{H}_{2} \mathrm{~S}$ 
and $\mathrm{CO}_{2}$ reporting that $\mathrm{Mg}-\mathrm{MOF}-74$, MIL-101(Cr), UiO-66, ZIF-8, and Ce-BTC had completely reversible physical adsorption of $\mathrm{H}_{2} \mathrm{~S}$; among them, MIL-101(Cr) exhibited the best separation performance for $\mathrm{H}_{2} \mathrm{~S} / \mathrm{CO}_{2}$. Liu et al. (2018a) reported a novel hybrid membrane, a rare earth, facecentered cubic-MOF (RE-fcu-MOF), modified by polymers, to remove $\mathrm{H}_{2} \mathrm{~S}$ and $\mathrm{CO}_{2}$ from natural gas. Recently, Huang and Wang (2019) reported core-shell structure $\mathrm{H}_{2} \mathrm{~S}$-imprinted polymers loaded on a polyoxometalate@Zr-based metalorganic framework using water as a substitution template to achieve the selective removal of $\mathrm{H}_{2} \mathrm{~S}$ from gases containing $\mathrm{CO}_{2}$. They found that this functional adsorbent had excellent separation for $\mathrm{H}_{2} \mathrm{~S} / \mathrm{CO}_{2}$, and could transform $\mathrm{H}_{2} \mathrm{~S}$ to sulphur. The results suggested that the adsorbent had excellent selectivity and desulfurization properties.

\section{Nitrogen Oxides}

$\mathrm{NO}_{x}$ compounds are the products of reactions between nitrogen and oxygen in high-temperature combustion processes, such as those associated with internal combustion engine exhaust and power station boilers. $\mathrm{NO}_{x}$ is a general term for all nitrogen oxides, including nitric oxide (NO) and nitrogen dioxide $\left(\mathrm{NO}_{2}\right)$, which belong to a type of air pollutants that can cause smog and acid rain $(\mathrm{Hu}$ et al., 2019). In addition, $\mathrm{NO}_{x}$ can react with ammonia, moisture, and other compounds to produce nitric acid, which causes considerable harm to lung tissue. Thus, the OSHA stipulated that the permissible exposure levels of $\mathrm{NO}$ and $\mathrm{NO}_{2}$ were 25 and 5 ppm, respectively (Decoste and Peterson, 2014). Current $\mathrm{NO}_{x}$ removal methods mainly include adsorption, absorption, catalytic decomposition, and selective catalytic reduction (Jiang et al., 2018). Adsorption has been widely studied for $\mathrm{NO}_{x}$ removal because of its advantages of a relatively high removal rate, no secondary pollution, and no energy loss. Therefore, various functional adsorbents, including MOF-based, carbon-based, zeolite-based, and composite materials (listed in Table 3), have been proposed to achieve highly effective removal of NO.

\section{Carbon-based Functional Materials}

Belhachemi et al. (2014) compared the $\mathrm{NO}_{2}$ adsorption capacities of different ACs, which were prepared through physical and chemical activation of date pits or obtained through the modification of commercialized AC. The

Table 3. Functional adsorbents for $\mathrm{NO}_{x}$ removal.

\begin{tabular}{|c|c|c|c|c|}
\hline Adsorbents & $\mathrm{NO}_{2}\left(\mathrm{mg} \mathrm{g}^{-1}\right)$ & $\mathrm{NO}\left(\mathrm{mg} \mathrm{g}^{-1}\right)$ & composition & Ref. \\
\hline $\mathrm{AC}$ & 39 & & $\mathrm{NO}_{2}$ in $\mathrm{N}_{2}$ & Yu et al. (2018) \\
\hline $\mathrm{C}_{\mathrm{CO} 2}$ & 129 & & & \\
\hline $\mathrm{C}_{\mathrm{Zn}}$ & 124 & & & \\
\hline GAC & 127 & & & \\
\hline GAC-O & 78 & & & \\
\hline GAC-O-T & 136 & & & \\
\hline Ordered mesoporous carbon (OMC) & & 16.35 & $\mathrm{NO}, \mathrm{O}_{2}$ in $\mathrm{Ar}$ & Ebrahim et al. (2014) \\
\hline $\mathrm{Ce}-\mathrm{OMC}$ & & 18.61 & & \\
\hline AC from sawdust & 54.7 & & $\mathrm{NO}_{2}$ in $\mathrm{N}_{2}$ & Choi et al. (2014) \\
\hline $\mathrm{AC}$ & & 11.3 & $\mathrm{NO}, \mathrm{O}_{2}$ in $\mathrm{Ar}$ & Mendt et al. (2017) \\
\hline $\mathrm{Cu} / \mathrm{AC}$ & & 42.39 & $\mathrm{NO}, \mathrm{O}_{2}$ in $\mathrm{N}_{2}$ & Zhao et al. (2017) \\
\hline $\mathrm{Zn} / \mathrm{AC}$ & & 34.23 & & \\
\hline M5AC7 & 16.3 & & $0.1 \%$ of $\mathrm{NO}_{2}$ & Chen et al. (2014) \\
\hline M7AC7 & 13.4 & & & \\
\hline M5AC8 & 12.0 & & & \\
\hline M7AC8 & 29.2 & & & \\
\hline$A-N_{2}-D-N_{2}$ & & 11.1 & $\mathrm{NO}, \mathrm{O}_{2}$ in $\mathrm{N}_{2}$ & Severa et al. (2015) \\
\hline $\mathrm{A}-\mathrm{O}_{2}-\mathrm{D}-\mathrm{N}_{2}$ & & 11.4 & & \\
\hline $\mathrm{A}-\mathrm{N}_{2}-\mathrm{O}_{2}-\mathrm{D}-\mathrm{N}_{2}$ & & 11.4 & & \\
\hline UiO-66 (dry) & 73 & & $\mathrm{NO}_{2}$ in $\mathrm{N}_{2}$ & Babu et al. (2016) \\
\hline UiO-66 (moist) & 40 & & & \\
\hline UiO-67 (dry) & 79 & & & \\
\hline UiO-67 (moist) & 118 & & & \\
\hline Urea/UiO-66 (dry) & 37 & & $\mathrm{NO}_{2}$ in $\mathrm{N}_{2}$ & Sun et al. (2016) \\
\hline Urea/UiO-66 (moist) & 101 & & & \\
\hline Melamine/UiO-66 (dry) & 3 & & & \\
\hline Melamine/UiO-66 (moist) & 10 & & & \\
\hline Urea/UiO-67 (dry) & 74 & & & \\
\hline Urea/UiO-67 (moist) & 154 & & & \\
\hline Melamine/UiO-67 (dry) & 41 & & & \\
\hline Melamine/UiO-67 (moist) & 93 & & & \\
\hline $\mathrm{MIPa}$ (AA as functional monomers) & & 0.121 & $\mathrm{NO}$ in $\mathrm{N}_{2}$ & Iberahim et al. (2018) \\
\hline $\mathrm{MIPb}$ (AAM as functional monomers) & & 0.112 & & \\
\hline
\end{tabular}


results demonstrated that the $\mathrm{AC}$ from date pits had a high $\mathrm{NO}_{2}$ adsorption capacity $\left(129 \mathrm{mg} \mathrm{g}^{-1}\right)$ similar to that of commercialized adsorbents. They also discovered that the presence of strong acidic groups such as carboxylic acids, anhydrides, and lactones inhibited the reduction of $\mathrm{NO}_{2}$ into NO. Wang et al. (2014) prepared AC fibers loaded with manganese dioxide $\left(\mathrm{MnO}_{2}\right)$ and studied the effect of the amount of $\mathrm{MnO}_{2}$ loading on the $\mathrm{NO}$ removal efficiency at room temperature. They found that appropriate amounts of $\mathrm{MnO}_{2}$ can improve the NO removal efficiency of $\mathrm{AC}$; moreover, the oxidation efficiency of NO reached $30.6 \%$ when the amount of $\mathrm{MnO}_{2}$ was $3.64 \mathrm{wt} \%$. Saputro et al. (2017) investigated the selectivity adsorption of the $\mathrm{ZnO}$ (0002) surface for NO and carbon monoxide by performing density functional theory (DFT) calculations. They found that a clean $\mathrm{ZnO}$ (0002) surface exhibited better selectivity for NO than for CO. Sager et al. (2016) studied the $\mathrm{NO}_{2}$ separation of $\mathrm{AC}$ modified with copper oxide $(\mathrm{CuO}) / \mathrm{ZnO}$ at an ambient temperature; when the loading amount of $\mathrm{CuO} / \mathrm{ZnO}$ was $20 \mathrm{wt} \%, \mathrm{CuO} / \mathrm{ZnO}-\mathrm{AC}$ demonstrated excellent removal ability for $\mathrm{NO}_{2}$. Bazan et al. (2016) prepared AC under different carbonization and activation temperatures to analyze the effects of these two factors on $\mathrm{NO}_{2}$ removal. Under dry conditions, $\mathrm{AC}$ that was prepared using carbonization and activation temperatures of $700^{\circ} \mathrm{C}$ and $800^{\circ} \mathrm{C}$, respectively, had the best $\mathrm{NO}_{2}$ adsorption capacity of $29.2 \mathrm{mg} \mathrm{g}^{-1}$. However, AC that was prepared using carbonization and activation temperatures of $500^{\circ} \mathrm{C}$ and $700^{\circ} \mathrm{C}$, respectively, exhibited the best removal capacity of $102.1 \mathrm{mg} \mathrm{g}^{-1}$ under mix-dry conditions. Guo et al. (2018) conducted the first study that used DFT to investigate the $\mathrm{NO}$ and $\mathrm{NO}_{2}$ adsorption behavior of pristine and B-atom-embedded $\gamma$-graphene. B-atom-embedded $\gamma$ graphene had stronger chemical interactions with $\mathrm{NO}$ and $\mathrm{NO}_{2}$ than pristine $\gamma$-graphene.

\section{Zeolite-based Functional Materials}

Sun et al. (2014b) compared the performance of 12 porous materials as adsorbents for removing $\mathrm{NO}_{x}$ from flue gases; these materials comprised four all-silica zeolites, six MOFs, and two zeolitic imidazolate frameworks (ZIFs). The results indicated that $\mathrm{Cu}$-BTC had the best adsorption of $\mathrm{NO}_{x}$, and the other adsorbents could not provide effective separation with large adsorption capacities for $\mathrm{NO}_{x}$; this shortcoming was attributed to the small dipole moment of $\mathrm{NO}_{x}$. Skarlis et al. (2014) investigated the storage of $\mathrm{NO}_{x}$ on Fe-BEA zeolite through Fourier transform infrared spectroscopy. Liu et al. (2015b) proposed a novel and ultrafast method to prepare high-silica zeolite SSZ-13 in $10 \mathrm{~min}$. After copper ion exchange, the prepared SSZ-13 exhibited excellent removal of $\mathrm{NO}_{x}$. Pan et al. (2015) studied the $\mathrm{NO}_{x}$ adsorption of $\mathrm{Fe} /$ zeolites in the presence of $\mathrm{SO}_{2}, \mathrm{CO}_{2}$ and water $\left(\mathrm{H}_{2} \mathrm{O}\right)$. The results revealed the $\mathrm{NO}_{x}$ adsorption capacities of the $\mathrm{Fe} /$ zeolite, which in descending order were as follows: Fe/MOR $>$ Fe/FER $>$ Fe/ZSM-5 $>$ $\mathrm{Fe} / \mathrm{Beta}$; moreover, the adsorption capacity of Fe/MOR for $\mathrm{NO}_{x}$ was approximately $3.2 \mathrm{mg} \mathrm{g}^{-1}$. In the presence of 100 ppm $\mathrm{SO}_{2}, 10 \% \mathrm{CO}_{2}$, and $10 \% \mathrm{H}_{2} \mathrm{O}$, the adsorption capacity of Fe/MOR for $\mathrm{NO}_{x}$ decreased to approximately $2.0 \mathrm{mg} \mathrm{g}^{-1}$.
Yu et al. (2018b) investigated the NO removal of HZSM-5 from flue gas through adsorption-plasma processes, including A- $\mathrm{N}_{2}-\mathrm{D}-\mathrm{N}_{2}$ (adsorption- $\mathrm{N}_{2}$ flushing-nonthermal plasma decomposition- $\mathrm{N}_{2}$ flushing), A-O $-\mathrm{D}-\mathrm{N}_{2}$ and $\mathrm{A}-\mathrm{N}_{2}-\mathrm{O}_{2}-\mathrm{D}-\mathrm{N}_{2}$.

\section{MOF-based Functional Materials}

Ebrahim et al. (2012) studied the $\mathrm{NO}_{2}$ adsorption properties of UiO-66 and $\mathrm{UiO}-67$ at ambient temperatures. An experiment comparing UiO-66 and UiO-67 indicated that the size and chemistry of a ligand influenced the adsorption property. In addition, UiO-66 demonstrated a more favorable adsorption capacity in dry conditions than in moist conditions, suggesting that water has a negative effect on $\mathrm{NO}_{2}$ adsorption. By contrast, the adsorption capacity of UiO-67 was higher under moist conditions than under dry conditions. On the basis of relevant research, the group utilized urea and melamine with $\mathrm{NH}_{2}$ groups to modify UiO-66 and UiO-67 and thus be capable of effectively removing $\mathrm{NO}_{2}$ under either dry or moist conditions. A series of experiments revealed that the adsorption capacity of every adsorbent was higher under moist conditions than under dry conditions. The adsorption capacities of both UiO-66 and UiO-67 modified with urea exhibited obvious increases compared with pure $\mathrm{UiO}-66$ and $\mathrm{UiO}-67$ under moist conditions. However, the introduction of melamine negatively affected the adsorption performance of UiO-66 and UiO-67 for $\mathrm{NO}_{2}$ (Ebrahim et al., 2014). Mendt et al. (2017) investigated the NO adsorption of MIL-100 (Al) at low temperatures by employing pulsed electron paramagnetic resonance spectroscopy and DFT calculations.

\section{Composite Materials}

Zhao et al. (2016) synthesized NO-MIPs by using methanoic acid as a dummy template because the solubility of NO is low in organic solvents under ambient conditions. In their study, they used acrylic acid (AA) and acryl amide (AAM) as functional monomers to prepare MIPa and $\mathrm{MIPb}$, respectively. The results demonstrated that the NO adsorption ability of MIPa was superior to that of $\mathrm{MIPb}$, suggesting that the acidic functional monomer AA is beneficial for improving NO adsorption capacity. Selectivity experiments revealed that $\mathrm{O}_{2}$ had no influence on $\mathrm{NO}$ adsorption capacity; the introduction of $\mathrm{CO}_{2}$ and $\mathrm{SO}_{2}$ led to the decrease of NO adsorption capacity. On the basis of their previous study, the group prepared two groups of NO-MIPs using methanoic acid, acetic acid, and ethanedioic acid as templates and AA and AAM as functional monomers. They discovered that the adsorbents with different functional monomers and templates had different pore sizes and surface areas, resulting in variations in adsorption capacity (Zhao and Wang, 2017).

\section{Sulfur Dioxide}

$\mathrm{SO}_{2}$ is a poisonous and colorless gas that is released mainly by the combustion of fossil fuel and waste incineration. $\mathrm{SO}_{2}$ can react with water vapor, $\mathrm{O}_{2}$, and other compounds to form acid rain. Moreover, it can cause the development of respiratory diseases and severely harm human organs such as stomachs, livers, and kidneys. $\mathrm{SO}_{2}$ 
removal is key method for improving air quality and human health (Hussain and Luo, 2019). In the past few years, researchers have proposed novel functional adsorbents such as carbon-based, zeolite-based, MOF-based, and composite materials to remove $\mathrm{SO}_{2}$, as indicated in Table 4.

\section{Carbon-based Functional Materials}

Peng et al. (2014) studied the selective adsorption ability of $\mathrm{AC}$ for $\mathrm{SO}_{2}$ and the desorption behavior of $\mathrm{AC}$ under microwave radiation. The selectivity result indicated that the presence of other gases in flue gas reduced the adsorption capacity to $28.73 \mathrm{mg} \mathrm{g}^{-1}$ for $\mathrm{SO}_{2}$. Yi et al. (2014) investigated the $\mathrm{SO}_{2}, \mathrm{NO}$ and $\mathrm{CO}_{2}$.removal abilities of coconut shell ACs modified with $\mathrm{Cu}, \mathrm{Ca}, \mathrm{Mg}$, and $\mathrm{Zn}$, respectively. They reported that the following order of $\mathrm{SO}_{2}$ adsorption capacity of each adsorbent: $\mathrm{Zn} / \mathrm{AC}<\mathrm{Cu} / \mathrm{AC}<$ $\mathrm{Mg} / \mathrm{AC}<\mathrm{Ca} / \mathrm{AC}$. Tailor et al. (2014) prepared a series of adsorbents, including PEI, and poly(propyleneimine) second and third generation ((PPI-G2 and PPI-G3, respectively) dendrimers supported on SBA-15 and MCM-41, and investigated the selective adsorption ability of each material for $\mathrm{SO}_{2}$. In the presence of mixture gas of $\mathrm{SO}_{2}$ and $\mathrm{N}_{2}$, the MCM-41 loaded with PPI-G3 exhibited the best selectivity for $\mathrm{SO}_{2} / \mathrm{N}_{2}$ compared with the other adsorbents.
In addition, the $\mathrm{SO}_{2}$ adsorption of MCM-41 loaded with PPI-G3 or PEI increased considerably under $19 \%$ relative humidity. Chen et al. (2014) obtained N-doped ordered mesoporous carbon spheres (N-OMCs) with a surface area of $566 \mathrm{~m}^{2} \mathrm{~g}^{-1}$ by using a soluble urea-phenol-formaldehyde resin as a precursor and triblock copolymer F127 as a soft template. The breakthrough time was $22.8 \mathrm{~min}$, and the $\mathrm{SO}_{2}$ adsorption capacity was $119.1 \mathrm{mg} \mathrm{g}^{-1}$. The $\mathrm{SO}_{2}$ adsorption capacity exhibited no obvious changes during seven cycle experiments, demonstrating that the adsorbent had stable adsorption. Zhang et al. (2015) investigated the $\mathrm{SO}_{2}$ adsorption of modified graphene oxides by performing DFT calculations and discovered that hydroxyl groups on graphene oxides can not only improve $\mathrm{SO}_{2}$ adsorption but also promote the oxidation of $\mathrm{SO}_{2}$ to $\mathrm{SO}_{3}$. To adsorb trace $\mathrm{SO}_{2}$, Ling et al. (2015) utilized a one-pot fabrication method of a calcium oxide $(\mathrm{CaO})$-carbon foam adsorbent, as shown in Fig. 5; the adsorbent had a hierarchical porous structure and retained a stable structure even after five cycles.

Severa et al. (2015) prepared ionic liquids (ILs) supported on $\mathrm{AC}$ to study $\mathrm{SO}_{2}$ adsorption. They discovered that ILs based on acetate and lactate imidazolium anions demonstrated favorable adsorption capacity for $\mathrm{SO}_{2}$ compared with those based on sulfate and halide anions. Sun et al. (2016)

Table 4. Functional adsorbents for $\mathrm{SO}_{2}$ removal.

\begin{tabular}{|c|c|c|c|c|}
\hline Adsorbents & $\mathrm{SO}_{2}\left(\mathrm{mg} \mathrm{g}^{-1}\right)$ & Temperature $\left({ }^{\circ} \mathrm{C}\right)$ & composition & Ref. \\
\hline $\mathrm{N}-\mathrm{OMC}$ & 119.1 & 25 & $\mathrm{SO}_{2}$ in $\mathrm{N}_{2}$ & Song et al. (2014) \\
\hline \multirow[t]{2}{*}{$\mathrm{MnO}_{2}$} & 200 & 250 & $\mathrm{SO}_{2}, \mathrm{CO}_{2}, \mathrm{O}_{2}$ and $\mathrm{H}_{2} \mathrm{O}$ & Savage et al. (2016) \\
\hline & 400 & 450 & & \\
\hline $\mathrm{GO}$ & 150 & 25 & $\mathrm{SO}_{2}$ & Zhang et al. (2016) \\
\hline Pure PC & 12.2 & 25 & $\mathrm{SO}_{2}$ in $\mathrm{N}_{2}$ & Glomb et al. (2017) \\
\hline $4.25 \% \mathrm{NPC}$ & 24.2 & & & \\
\hline $7.57 \% \mathrm{NPC}$ & 35.3 & & & \\
\hline $10.2 \% \mathrm{NPC}$ & 48.3 & & & \\
\hline Macro and micro GO & 190.1 & 20 & $\mathrm{SO}_{2}$ & Elder et al. (2018) \\
\hline POSB & 10.04 & 400 & $\mathrm{SO}_{2}$ in $\mathrm{N}_{2}$ & Mon et al. (2018) \\
\hline MDEA/AC after $\mathrm{CO}_{2}$ activation & 156.22 & 120 & $1 \% \mathrm{SO}_{2}$ in $\mathrm{N}_{2}$ & Carter et al. (2018) \\
\hline PILs-xerogels & 514 & 25 & $\mathrm{SO}_{2}$ in $\mathrm{N}_{2}$ & Xia et al. (2018) \\
\hline \multirow[t]{2}{*}{ Propyldiethanolamine/MCM-41 } & 181.8 & 23 & $1 \% \mathrm{SO}_{2}$ in $\mathrm{N}_{2}$ & Khan et al. (2000) \\
\hline & 137 & 50 & & \\
\hline Triethylolamine/SBA-15 & 146.3 & 25 & $\mathrm{SO}_{2}$ in $\mathrm{N}_{2}$ & Quijano et al. (2011) \\
\hline MFM-300(In) & 529.9 & 25 & $\mathrm{SO}_{2}, \mathrm{CO}_{2}$ in $\mathrm{N}_{2}$ & Wang et al. (2017b) \\
\hline MFM-601 & 787.2 & 25 & $\mathrm{SO}_{2}$ & Zhou et al. (2018) \\
\hline
\end{tabular}
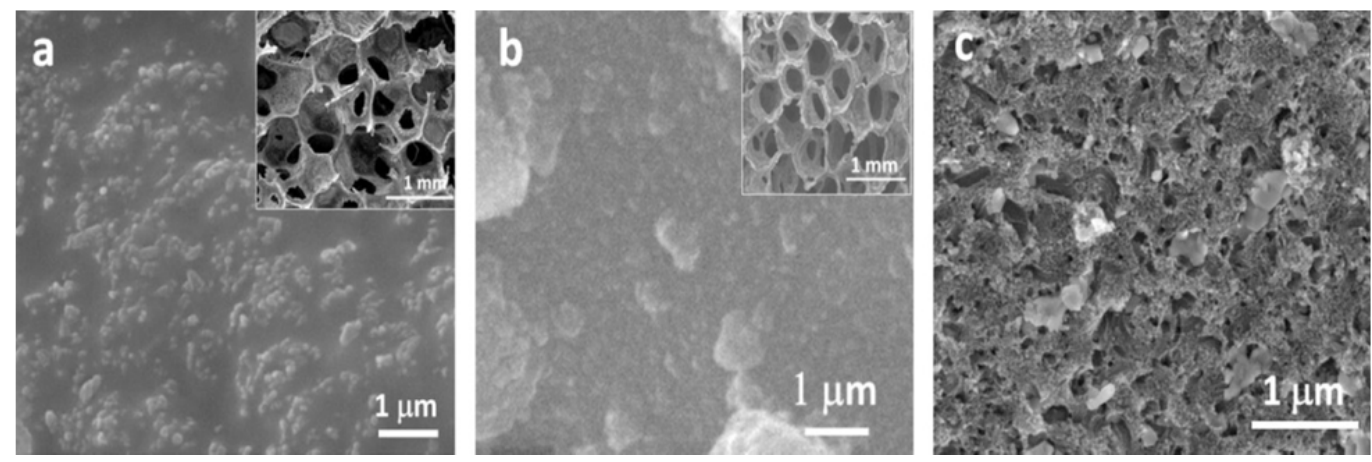

Fig. 5. SEM images of $\mathrm{CaO} /$ carbon foam before heat treatment (a), before use (b) and after 5 cycles (c) (Ling et al., 2015). 
investigated how the amount of nitrogen loaded on the surface of NPCs affect $\mathrm{SO}_{2}$ adsorption. The results demonstrated that the introduction of $\mathrm{N}$ can noticeably enhance the $\mathrm{SO}_{2}$ adsorption capacity of porous carbon. On the basis of research on the use of palm oil mill sludge, Iberahim et al. (2018) prepared biochar through the pyrolysis method and studied its $\mathrm{SO}_{2}$ adsorption ability. To further improve the $\mathrm{SO}_{2}$ adsorption of AC, Shao et al. (2018b) used $\mathrm{CO}_{2}$ activation and methyldiethanolamine (MDEA) impregnation to modify $\mathrm{AC}$; the $\mathrm{SO}_{2}$ adsorption capacity of $\mathrm{AC}$ increased from 57.78 to $156.22 \mathrm{mg} \mathrm{g}^{-1}$ after MDEA impregnation, demonstrating that MDEA impregnation treatment can effectively enhance the adsorption capacity of AC. Xia et al. (2018) designed a highly cross-linked nonporous poly(ionic liquid) xerogels through the polymerization of gemini ILs. Selectivity experiments demonstrated that the xerogels had no adsorption ability for $\mathrm{CO}_{2}, \mathrm{CH}_{4}$, or $\mathrm{N}_{2}$, but the adsorption capacity for $\mathrm{SO}_{2}$ reached $514 \mathrm{mg} \mathrm{g}^{-1}$. The $\mathrm{SO}_{2}$ adsorption capacity exhibited no remarkable changes after 50 cycle experiments. The results demonstrated that the prepared xerogels had remarkable adsorption performance for $\mathrm{SO}_{2}$ and excellent regeneration ability.

\section{MOF-based Functional Materials}

Using the grand canonical Monte Carlo simulation method, Song et al. (2014) studied the $\mathrm{SO}_{2}$ adsorption properties of MOFs with different pore sizes and topologies, including IRMOF-1, -8, -9, -10, and -15; MOF-177 and -505; Cu-BTC; MIL-47; and ZIF-8. The simulation results revealed that the MOFs with pore sizes larger than $0.4 \mathrm{~nm}$ exhibited excellent adsorption of $\mathrm{SO}_{2}$. Savage et al. (2016) prepared porous MOF (MFM-300 (In)) and studied the selective adsorption of $\mathrm{SO}_{2}$ with interference of $\mathrm{CO}_{2}, \mathrm{CH}_{4}$, and $\mathrm{N}_{2}$ individually. The results demonstrated that MFM300 (In) had a high $\mathrm{SO}_{2}$ adsorption capacity of $529.9 \mathrm{mg} \mathrm{g}^{-1}$ and favorable selectivity for $\mathrm{SO}_{2} / \mathrm{CO}_{2}(60), \mathrm{SO}_{2} / \mathrm{CH}_{4}(425)$, and $\mathrm{SO}_{2} / \mathrm{N}_{2}$ (5000) under ambient conditions. Mounfield et al. (2016) studied the adsorption performance of MIL-125 and MIL-125- $\mathrm{NH}_{2}$ for $\mathrm{SO}_{2}$ at 2.7 bar and found that the

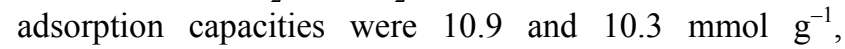
respectively. In addition, they discovered that MIL-125- $\mathrm{NH}_{2}$ can retain a stable structure under dry, humid, and aqueous $\mathrm{SO}_{2}$ conditions. However, MIL-125 degraded when exposed to humid and aqueous $\mathrm{SO}_{2}$, indicating that its stability requires improvement. Considering that ZIFs demonstrate favorable stability with respect to temperature and humidity, Bhattacharyya et al. (2016) studied the adsorption performance of ZIF-8 for $\mathrm{SO}_{2}$ and analyzed its stability under dry, humid, and aqueous $\mathrm{SO}_{2}$ conditions. The $\mathrm{SO}_{2}$ saturation capacity was approximately $518.4 \mathrm{mg} \mathrm{g}^{-1}$ at $25^{\circ} \mathrm{C}$ and 2.5 bar in a dry environment. Characterization revealed that dry $\mathrm{SO}_{2}$ had no influence on the stability of ZIF-8 at room temperature, humid $\mathrm{SO}_{2}$ attacked the structure of ZIF-8, and ZIF-8 exhibited no structural degradation under aqueous $\mathrm{SO}_{2}$ conditions. Ranjbar and Taher (2016) studied the adsorption property of Ni-MOF-74 for $\mathrm{SO}_{2}$ at $25^{\circ} \mathrm{C}$ under the pressure range of 0 to 4 bar. The $\mathrm{SO}_{2}$ adsorption capacity of Ni-MOF-74 increased in with the pressure, and the maximum capacity of $105.06 \mathrm{mmol} \mathrm{g}^{-1}$ was reached at 4 bar. Zhang et al. (2016) compared the $\mathrm{SO}_{2}$ adsorption capacities of four MOFs loaded with polyacrylonitrile (PAN) - PAN/ZIF-8, PAN/Mg-MOF-74, PAN/MOF-199, PAN/UiO-66- $\mathrm{NH}_{2}$ - and reported that the PAN supported by the four MOFs had an adsorption ability that was superior to that of pure PAN; moreover, PAN/UiO-66- $\mathrm{NH}_{2}$ exhibited the highest adsorption capacity of approximately $11 \mathrm{mg} \mathrm{g}^{-1}$ at $25^{\circ} \mathrm{C}$. Glomb et al. (2017) prepared four dicarboxylate modified MOFs for $\mathrm{SO}_{2}$ adsorption: $3 \mathrm{D}-\left[\mathrm{Zn}_{4}\left(\mu_{4}-\mathrm{O}\right)(\mathrm{L} 1)_{3}\right]$, $2 \mathrm{D}$ $\left[\mathrm{Zn}_{2}(\mathrm{~L} 1)_{2}(\mathrm{DEF})_{2} \cdot 2.5 \mathrm{DEF}\right], \quad\left[\mathrm{Zn}_{2}(\mathrm{~L} 1)_{2}\right.$ (bipy) $] \quad$ and $\left[\mathrm{Zn}_{2}(\mathrm{~L} 1)_{2}\right.$ (bpe)]. Among them, $\left[\mathrm{Zn}_{2}(\mathrm{~L} 1)_{2}\right.$ (bipy)] exhibited the highest $\mathrm{SO}_{2}$ adsorption capacity of $10.9 \mathrm{mmol} \mathrm{g}^{-1}$ at $293 \mathrm{~K}$ and 1 bar. Elder et al. (2018) investigated the adsorption performance of copper benzenedicarboxylate (CuBDC), zinc benzenedicarboxylate ( $\mathrm{ZnBDC}$ ) and cobalt benzenedicarboxylate (CoBDC) for humid $\mathrm{SO}_{2} ; 88 \%$ of the $\mathrm{SO}_{2}$ was adsorbed by $\mathrm{CuBDC}$ in a reduced oxidation state. Moreover, the structures of $\mathrm{ZnBDC}$ and CoBDC underwent changes when exposed to $\mathrm{SO}_{2}$; this indicated that they were unsuitable for application in $\mathrm{SO}_{2}$ removal. Mon et al. (2018) proposed a novel 3D MOF with hydrated barium cations for selective adsorption of $\mathrm{SO}_{2}$, and the $\mathrm{SO}_{2}$ adsorption capacity reached $2.5 \mathrm{mmol} \mathrm{g}^{-1}$ at $303 \mathrm{~K}$ and 0.025 bar. Carter et al. (2018) reported that a novel MFM-601 had a record-high $\mathrm{SO}_{2}$ adsorption capacity of $12.3 \mathrm{mmol} \mathrm{g}^{-1}$ at $298 \mathrm{~K}$ and $1.0 \mathrm{bar}$; furthermore, the adsorbent exhibited fully reversible and highly selective adsorption for $\mathrm{SO}_{2}$ with respect to $\mathrm{CO}_{2}$ and $\mathrm{N}_{2}$.

Cui et al. (2017) designed an inorganic anion-pillared hybrid porous adsorbent (silicon hexafluoride, $\mathrm{SiF}_{6}{ }^{-2}$ ) to achieve the efficient capture of $\mathrm{SO}_{2}$; a high $\mathrm{SO}_{2}$ adsorption capacity of $704.6 \mathrm{mg} \mathrm{g}^{-1}$ was reached at $1.01 \mathrm{bar}$, and an excellent $\mathrm{SO}_{2} / \mathrm{CO}_{2}$ selectivity of $89 \%$ was achieved at a low pressure (0.002 bar).

\section{Volatile Organic Compounds}

VOCs are a type of common air pollutant emitted through production in chemical, petrochemical, and related industries; some examples of these pollutants are benzene, toluene, hexane, $\mathrm{CH}_{4}$ and sulfur compounds (Khan and Ghoshal, 2000). Deng et al. (2018) analyzed 36 VOCs from Longchuan Tunnel, Hefei, in eastern China, to study the atmospheric VOC pollution in urban areas of China. They found that alkanes (mainly branched alkanes) accounted for the largest proportion of $52 \%$, and benzene homologues took the second place. These gases cause serious harm to the environment and human health, including by causing nausea, exposing humans to carcinogens, and contributing to global warming (Quijano et al., 2011). Therefore, many absorbents and catalysts have been developed for the removal of VOCs. For example, some researchers have investigated the potential of using ILs as absorbents for VOC removal (Park et al., 2017; Wang et al., 2017a). Quijano et al. (2011) assessed the feasibility of using imidazole ILs for VOC removal in a multiphase bioreactor. The results suggested that the acclimation of VOCs by microorganisms alone was insufficient for achieving effective biodegradation in heterogeneous systems such as nonaqueous-phase ILs. 
Wang et al. (2017b) investigated the adsorption potential of a [Bmim] [NTf2] absorbent for toluene. The solubility of toluene in [Bmim] [NTf2] was $61.5 \%$ at $20^{\circ} \mathrm{C}$ and standard atmospheric pressure. The maximum adsorption rate of toluene for [Bmim] [NTf2] was $98.3 \%$. At a concentration

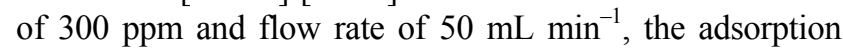
rate of toluene could exceed $94 \%$ at $20^{\circ} \mathrm{C}$. The results indicated that [Bmim] [NTf2] absorbents can remove toluene easily. Biard et al. (2018) simulated the countercurrent adsorption of four hydrophobic VOCs and two heavy organic solvents, namely polydimethylsioxane (PDMS) 50 and di-(2-ethylhexyl) adipate (DEHA), using fixed volume packed columns. VOC biodegradation experiments revealed that $5 \%\left(\mathrm{v} \mathrm{v}^{-1}\right)$ IL was toxic to activated sludge organisms, and the combination of IL and VOC may produce a synergistic toxic effect. After the domestication of target VOCs, only toluene biodegradability increased significantly in response to IL. The results revealed that ILs could strongly inhibit microbial activity in the presence of VOCs for more than 24 hours. Mo et al. (2019) reported that photocatalytic oxidation is a promising method for the removal of VOCs and reviewed the purification status of VOCs in indoor air. Park et al. (2017) investigated several strategies for removing VOCs from the atmosphere. VOCs could be effectively captured using activated carbon fiber (ACF) and mesoporous silica with high surface areas. Biard et al. (2016) utilized a simple dynamic adsorption method to evaluate the mass transfer performance of solvents for selective removal of VOCs. Four hydrophobic VOCs (toluene, acetone, dichloromethane, and isopropanol) were absorbed by water and two heavy organic solvents, namely DEHA and PDMS. The water had high selectivity, and the two organic solvents, especially DEHA, demonstrated strong binding affinity for all VOCs.

Fang et al. (2016) prepared a series of new paraffin/ surfactant/water emulsion (PSW) materials, and studied their potential for VOC removal. PSW-5 $\left(5 \%, \mathrm{v} \mathrm{v}^{-1}\right)$ had higher adsorption efficiency for toluene than did other absorbents. The absorptivity of PSW-5 towards toluene reached $82.42 \%$, and it remained $82.42 \%$ after three cycles. $\mathrm{Yu}$ et al. (2018a) selected benzene, toluene and xylene (BTX) as VOC representatives to measure the vapor-liquid equilibrium of BTX+ [EMIM] [Tf2N] mixtures. Cardoso et al. (2008) prepared ACs using cork powder waste as the raw material, and studied the adsorption potential of ACs for VOCs. Three ACs were prepared through the chemical activation of cork powder waste with $\mathrm{KOH}$ as the activator. The adsorbent had a large surface area exceeding $1300 \mathrm{~m}^{2}$ $\mathrm{g}^{-1}$ and a micropore volume greater than $0.5 \mathrm{~cm}^{3} \mathrm{~g}^{-1}$. They discovered that the adsorbent at the highest activation temperature and $\mathrm{KOH}$ dosage exhibited the best removal and selective adsorption performance for VOCs.

Wang et al. (2016) developed hydrophobic functionalized SBA-15 through synthesis and post-modification of trimethylchlorosilane (TMCS) to remove VOCs. The adsorption and desorption properties of SBA-15-TMCS under various static and dynamic conditions were studied. The designed SBA-15-TMCS had high VOC adsorption capacity and recycling capacity. Zhou et al. (2018a) studied the effect of membrane adsorption on VOC recovery from oil and gas. The removal rate of heat-conducting oil absorbent was $86.50 \%$, and that of an AbsFOV-97 absorbent was 90.44\%. The performance of ABFOV-97 was superior to that of the heat-conducting oil. Moreover, a lower gas flow rate led to higher recovery from oil and gas. When the gas

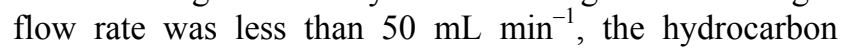
removal rate was approximately $99.50 \%$.

In addition, Iuga et al. (2011) used pyridine as the target molecules and MAA as the functional monomers to form a specific MIP, which demonstrated had strong selectivity for pyridine in the presence of toluene and benzene.

\section{SUMMARY}

In conclusion, the adsorption and regeneration properties of adsorbents require improvement in terms of working adsorption capacity, cycle life, and stability. To obtain a techno-economic system, the development of a new type of highly efficient adsorbent is necessary. In addition, few studies have been conducted in recent years on MIPs in the field of gas separation and removal, especially that of $\mathrm{H}_{2} \mathrm{~S}$, $\mathrm{SO}_{2}$, and $\mathrm{NO}_{x}$. Therefore, designing functional adsorbents with excellent selectivity, adsorption and regeneration properties should be the focus of future research.

\section{ACKNOWLEDGMENTS}

This work was supported by the National Natural Science Foundation of China [Nos: 21276144, 21511130021], the Key Research and Development Program of Shandong Province, China [2017GSF217006], and Foundation of State Key Laboratory of High-efficiency Utilization of Coal and Green Chemical Engineering [No: 2017-K30].

\section{REFERENCES}

Abdullah, A.H., Mat, R., Somderam, S.A., Aziz, S.A. and Mohamed, A. (2018). Hydrogen sulfide adsorption by zinc oxide-impregnated zeolite (synthesized from Malaysian kaolin) for biogas desulfurization. J. Ind. Eng. Chem. 65: 334-342.

Akinyele, D.O. and Rayudu, R.K. (2014). Review of energy storage technologies for sustainable power networks. Sustainable Energy Technol. Assess. 8: 7491.

Al-Jadir, T.M. and Siperstein, F.R. (2018). The influence of the pore size in Metal-Organic Frameworks in adsorption and separation of hydrogen sulphide: A molecular simulation study. Microporous Mesoporous Mater. 271: 160-168.

An, H., Feng, B. and Su, S. (2009). $\mathrm{CO}_{2}$ capture by electrothermal swing adsorption with activated carbon fibre materials. Carbon 47: 2396-2405.

Asad, M. and Sheikhi, M.H. (2014). Surface acoustic wave based $\mathrm{H}_{2} \mathrm{~S}$ gas sensors incorporating sensitive layers of single wall carbon nanotubes decorated with $\mathrm{Cu}$ nanoparticles. Sens. Actuators, B 198: 134-141.

Babu, D.J., Kühl, F.G., Yadav, S., Markert, D., Bruns, M., 
Hampe, M.J. and Schneider, J.J. (2016). Adsorption of pure $\mathrm{SO}_{2}$ on nanoscaled graphene oxide. RSC $A d v$. 6: 36834-36839.

Balsamo, M., Cimino, S., De Falco, G., Erto, A. and Lisi, L. (2016). $\mathrm{ZnO}-\mathrm{CuO}$ supported on activated carbon for $\mathrm{H}_{2} \mathrm{~S}$ removal at room temperature. Chem. Eng. J. 304: 399-407.

Barelli, L., Bidini, G., Micoli, L., Sisani, E. and Turco, M. (2018). 13X Ex-Cu zeolite performance characterization towards $\mathrm{H}_{2} \mathrm{~S}$ removal for biogas use in molten carbonate fuel cells. Energy 160: 44-53.

Bazan, A., Nowicki, P. and Pietrzak, R. (2016). Removal of $\mathrm{NO}_{2}$ by carbonaceous adsorbents obtained from residue after supercritical extraction of marigold. Adsorption 22: 465-471.

Beidari, M., Lin, S. and Lewis, C. (2017). Multiplier effects of energy consumption and $\mathrm{CO}_{2}$ emissions by input-output analysis in South Africa. Aerosol Air Qual. Res. 17: 1666-1678.

Belhachemi, M., Jeguirim, M., Limousy, L., Addoun, F. (2014). Comparison of $\mathrm{NO}_{2}$ removal using date pits activated carbon and modified commercialized activated carbon via different preparation methods: Effect of porosity and surface chemistry. Chem. Eng. J. 253: 121129.

Belmabkhout, Y., Serna-Guerrero, R. and Sayari, A. (2010) Microporous carbonaceous adsorbents for $\mathrm{CO}_{2}$ separation via selective adsorption. Chem. Eng. Sci. 65: 3695-3698.

Bhatt, P.M., Belmabkhout, Y., Assen, A.H., Weseliński, Ł.J., Jiang, H., Cadiau, A., Xue, D. and Eddaoudi, M. (2017). Isoreticular rare earth fcu-MOFs for the selective removal of $\mathrm{H}_{2} \mathrm{~S}$ from $\mathrm{CO}_{2}$ containing gases. Chem. Eng. J. 324: 392-396.

Bhattacharyya, S., Pang, S.H., Dutzer, M.R., Lively, R.P., Walton, K.S., Sholl, D.S. and Nair, S. (2016). Interactions of $\mathrm{SO}_{2}$-containing acid gases with ZIF-8: structural changes and mechanistic investigations. $J$. Phys. Chem. C 120: 27221-27229.

Biard, P., Coudon, A., Couvert, A. and Giraudet, S. (2016). A simple and timesaving method for the mass-transfer assessment of solvents used in physical absorption. Chem. Eng. J. 290: 302-311.

Biard, P., Couvert, A. and Giraudet, S. (2018). Volatile organic compounds adsorption in packed column: Theoretical assessment of water, DEHA and PDMS50 as absorbents. J. Ind. Eng. Chem. 59: 70-78.

Boysen, R. (2018). Advances in the development of molecularly imprinted polymers for the separation and analysis of proteins with liquid chromatography. J. Sep. Sci. 42: 51-71.

Cao, F., Chen, J., Ni, M., Song, H., Xiao, G., Wu, W., Gao, X. and Cen, K. (2014). Adsorption of NO on ordered mesoporous carbon and its improvement by cerium. RSC Adv. 4: 16281-16289.

Cara, C., Rombi, E., Musinu, A., Mameli, V., Ardu, A., Angotzi, M.S., Atzori, L., Niznansky, D., Xin, H.L. and Cannas, C. (2017). MCM-41 support for ultrasmall $\gamma$ $\mathrm{Fe}_{2} \mathrm{O}_{3}$ nanoparticles for $\mathrm{H}_{2} \mathrm{~S}$ removal. J. Mater. Chem. A

\section{5: 21688-21698.}

Cara, C., Rombi, E., Mameli, V., Ardu, A., Sanna Angotzi, M., Niznansky, D., Musinu, A. and Cannas, C. (2018). $\gamma-\mathrm{Fe}_{2} \mathrm{O}_{3}-\mathrm{M}_{41} \mathrm{~S}$ sorbents for $\mathrm{H}_{2} \mathrm{~S}$ removal: Effect of different porous structures and silica wall thickness. $J$. Phys. Chem. C 122: 12231-12242.

Cardoso, B., Mestre, A., Carvalho, A. and Pires, J. (2008) Activated carbon derived from cork powder waste by $\mathrm{KOH}$ activation: preparation, characterization, and VOCs adsorption. Ind. Eng. Chem. Res. 47: 5841-5846.

Carter, J.H., Han, X., Moreau, F.Y., Silva, I. da, Nevin, A., Godfrey, H.G., Tang, C., Yang, S. and Schröder, M. (2018). Exceptional adsorption and binding of sulfur dioxide in a robust zirconium-based metal-organic framework. J. Am. Chem. Soc. 140: 15564-15567.

Chen, A., Yu, Y., Zhang, Y., Zang, W., Yu, Y., Zhang, Y., Shen, S. and Zhang, J. (2014). Aqueous-phase synthesis of nitrogen-doped ordered mesoporous carbon nanospheres as an efficient adsorbent for acidic gases. Carbon 80: 19-27.

Chen, C., Yang, S., Ahn, W., Ryoo, R. (2009). Amineimpregnated silica monolith with a hierarchical pore structure: Enhancement of $\mathrm{CO}_{2}$ capture capacity. Chem. Commun. 24: 3627-3629.

Chen, C., Son, W., You, K., Ahn, J. and Ahn, W. (2010). Carbon dioxide capture using amine-impregnated HMS having textural mesoporosity. Chem. Eng. J. 161: 4652.

Chen, X., Shen, B. and Sun, H. (2018a). Ion-exchange modified zeolites $\mathrm{X}$ for selective adsorption desulfurization from Claus tail gas: Experimental and computational investigations. Microporous Mesoporous Mater. 261: 227-236.

Chen, Y., Qiao, Z., Huang, J., Wu, H., Xiao, J., Xia, Q., $\mathrm{Xi}, \mathrm{H} ., \mathrm{Hu}$, J., Zhou, J. and Li, Z. (2018b). Unusual Moisture-enhanced $\mathrm{CO}_{2}$ Capture within Microporous PCN-250 Frameworks. ACS Appl. Mater. Interfaces 44: 38638-38647.

Cheong, W., Yang, S. and Ali, F. (2013). Molecular imprinted polymers for separation science: A review of reviews. J. Sep. Sci. 36: 609-628.

Choi, S.J., Jang, B.H., Lee, S.J., Min, B.K., Rothschild, A. and Kim, I.D. (2014). Selective detection of acetone and hydrogen sulfide for the diagnosis of diabetes and halitosis using $\mathrm{SnO}_{2}$ nanofibers functionalized with reduced graphene oxide nanosheets. ACS Appl. Mater. Interfaces 6: 2588-2597.

Chu, J., Wang, X., Wang, D., Yang, A., Lv, P., Wu, Y., Rong, M. and Gao, L. (2018). Highly selective detection of sulfur hexafluoride decomposition components $\mathrm{H}_{2} \mathrm{~S}$ and $\mathrm{SOF}_{2}$ employing sensors based on tin oxide modified reduced graphene oxide. Carbon 135: 95-103.

Cimino, S., Lisi, L., de Falco, G., Montagnaro, F., Balsamo, M. and Erto, A. (2018). Highlighting the effect of the support during $\mathrm{H}_{2} \mathrm{~S}$ adsorption at low temperature over composite Zn-Cu sorbents. Fuel 221: 374-379.

Cui, X., Yang, Q., Yang, L., Krishna, R., Zhang, Z., Bao, Z., Wu, H., Ren, Q., Zhou, W., Chen, B. and Xing, H. (2017). Ultrahigh and selective $\mathrm{SO}_{2}$ uptake in inorganic 
anion-pillared hybrid porous materials. Adv. Mater. 29: 1606929.

DeCoste, J.B. and Peterson, G.W. (2014). Metal-organic frameworks for air purification of toxic chemicals. Chem. Rev. 114: 5695-5727.

Demir, H., Walton, K.S. and Sholl, D.S. (2017). Computational screening of functionalized UiO-66 materials for selective contaminant removal from air. $J$. Phys. Chem. C 121: 20396-20406.

Deng, C., Jin, Y., Zhang, M., Liu, X. and Yu, Z. (2018). Emission characteristics of VOCs from on-road vehicles in an urban tunnel in eastern China and predictions for 2017-2026. Aerosol Air Qual. Res. 18: 3025-3034.

Duong-Viet, C., Liu, Y., Ba, H., Truong-Phuoc, L., Baaziz, W., Nguyen-Dinh, L., Jean-Mario, N. and Pham-Huu, C. (2016). Carbon nanotubes containing oxygenated decorating defects as metal-free catalyst for selective oxidation of $\mathrm{H}_{2}$ S. Appl. Catal. B 191: 29-41.

Ebrahim, A.M., Levasseur, B. and Bandosz, T.J. (2012) Interactions of $\mathrm{NO}_{2}$ with $\mathrm{Zr}$-based MOF: effects of the size of organic linkers on $\mathrm{NO}_{2}$ adsorption at ambient conditions. Langmuir 29: 168-174.

Ebrahim, A.M. and Bandosz, T.J. (2014). Effect of amine modification on the properties of zirconium-carboxylic acid based materials and their applications as $\mathrm{NO}_{2}$ adsorbents at ambient conditions. Microporous Mesoporous Mater. 188: 149-162.

Elder, A.C., Bhattacharyya, S., Nair, S. and Orlando, T.M. (2018). Reactive adsorption of humid $\mathrm{SO}_{2}$ on metalorganic framework nanosheets. J. Phys. Chem. C 122: 10413-10422.

Elsabawy, K. and Fallatah, A. (2019). Synthesis of newly wings like structure non-crystalline Nipp-1,3,5-tribenzyl1,3,5-triazine-2,4,6-(1H,3H,5H)-trione coordinated MOFs for $\mathrm{CO}_{2}$ Capture. J. Mol. Struct. 1177: 255-259.

Elyassi, B., Al Wahedi, Y., Rajabbeigi, N., Kumar, P., Jeong, J.S., Zhang, X., Kumar, P., Balasubramanian, V., Katsiotis, M., Andre Mkhoyan, K., Boukos, N., Al Hashimi, S. and Tsapatsis, M. (2014). A high-performance adsorbent for hydrogen sulfide removal. Microporous Mesoporous Mater. 190: 152-155.

Fang, P., Tang, Z., Chen, X., Tang, Z., Chen, D., Huang, J., Zeng, W. and Cen, C. (2016). Experimental study on the adsorption of toluene from exhaust gas by paraffin/surfactant/water emulsion. J. Chem. 2016: 9385027.

Farooq, M., Almustapha, M.N., Imran, M., Saeed, M.A. and Andresen, J.M. (2018). In-situ regeneration of activated carbon with electric potential swing desorption (EPSD) for the $\mathrm{H}_{2} \mathrm{~S}$ removal from biogas. Bioresour. Technol. 249: 125-131.

Fauteux-Lefebvre, C., Abatzoglou, N., Blais, S., Braidy, N. and Hu, Y. (2015). Iron oxide-functionalized carbon nanofilaments for hydrogen sulfide adsorption: The multiple roles of carbon. Carbon 95: 794-801.

Gholidoust, Maina, J., Merenda, A., Schütz, J., Kong, L., Hashisho, Z. and Dumée, L. (2019). $\mathrm{CO}_{2}$ sponge from plasma enhanced seeded growth of metal organic frameworks across carbon nanotube bucky-papers. Sep.
Purif. Technol. 209: 571-579.

Glomb, S., Woschko, D., Makhloufi, G. and Janiak, C. (2017). Metal-organic frameworks with internal ureafunctionalized dicarboxylate linkers for $\mathrm{SO}_{2}$ and $\mathrm{NH}_{3}$ adsorption. ACS Appl. Mater. Interfaces 9: 37419-37434.

Gonçalves, D.V., Paiva, M.A., Oliveira, J.C., Bastos-Neto, M.S. and Lucena, M. (2018). Prediction of the monocomponent adsorption of $\mathrm{H}_{2} \mathrm{~S}$ and mixtures with $\mathrm{CO}_{2}$ and $\mathrm{CH}_{4}$ on activated carbons. Colloids Surf. $A$ 559: 342-350.

Guo, Y., Chen, Z., Wu, W., Liu, Y. and Zhou, Z. (2018) Adsorption of $\mathrm{NO}_{x}(\mathrm{x}=1,2)$ gas molecule on pristine and $\mathrm{B}$ atom embedded $\gamma$-graphyne based on first-principles study. Appl. Surf. Sci. 455: 484-491.

Gupta, A.K., Ibrahim, S. and Shoaibi, A. (2016). Advances in sulfur chemistry for treatment of acid gases. Prog. Energy Combust. Sci. 54: 65-92.

Habeeb, O., Kanthasamy, R., Ali, G., Sethupathi, S., and Yunus, R. (2017). Hydrogen sulfide emission sources, regulations, and removal techniques: A review. Rev. Chem. Eng. 34: 837-854.

Hamon, L., Leclerc, H., Ghoufi, A., Oliviero, L., Travert, A., Lavalley, J.C., Devic, T., Serre, C., Ferey, G., Vimont, A. and Maurin, G. (2011). Molecular insight into the adsorption of $\mathrm{H}_{2} \mathrm{~S}$ in the flexible MIL-53 (Cr) and rigid MIL-47 (V) MOFs: infrared spectroscopy combined to molecular simulations. J. Phys. Chem. C 115: 2047-2056.

Hao, X., Hou, G., Zheng, P., Liu, R. and Liu, C. (2016). $\mathrm{H}_{2} \mathrm{~S}$ in-situ removal from biogas using a tubular zeolite $/ \mathrm{TiO}_{2}$ photocatalytic reactor and the improvement on methane production. Chem. Eng. J. 294: 105-110.

He, H., Zhuang, L., Chen, S. and Liu, H. (2016). A solid amine adsorbent prepared by molecularly imprinting and its $\mathrm{CO}_{2}$ adsorption properties. Chem. Asian J. 11: 3055.

Hu, Y., Li, Z., Wang, Y., Wang, L., Zhu, H., Chen, L., Guo, X., An, C., Jiang, Y. and Liu, A. (2019). Emission factors of $\mathrm{NO}_{\mathrm{x}}, \mathrm{SO}_{2}, \mathrm{PM}$ and VOCs in pharmaceuticals, brick and food industries in Shanxi, China. Aerosol Air Qual. Res. 19: 1785-1797.

Huang, Y. and Wang, R. (2018). Review on fundamentals, preparations and applications of imprinted polymers. Curr. Org. Chem. 22: 1600-1618.

Huang, Y. and Wang, R. (2019). Highly selective separation of $\mathrm{H}_{2} \mathrm{~S}$ and $\mathrm{CO}_{2}$ using a $\mathrm{H}_{2} \mathrm{~S}$-imprinted polymers loaded on a polyoxometalate@zr-based metal-organic framework with a core-shell structure at ambient temperature. $J$. Mater. Chem. A 7: 12105-12114.

Huang, Z.H., Liu, G. and Kang, F. (2012). Glucosepromoted Zn-based metal-organic framework/graphene oxide composites for hydrogen sulfide removal. $A C S$ Appl. Mater. Interfaces. 4: 4942-4947.

Huang, Z.B., Liu, B.S., Wang, F. and Amin, R. (2015). Performance of $\mathrm{Zn}-\mathrm{Fe}-\mathrm{Mn} / \mathrm{MCM}-48$ sorbents for high temperature $\mathrm{H}_{2} \mathrm{~S}$ removal and analysis of regeneration process. Appl. Surf. Sci. 353: 1-10.

Hussain, R. and Luo, K. (2019). The geological availability and emissions of sulfur and $\mathrm{SO}_{2}$ from the typical coal of China. Aerosol Air Qual. Res. 19: 559-570. 
Iberahim, N., Sethupathi, S. and Bashir, M.J. (2018). Optimization of palm oil mill sludge biochar preparation for sulfur dioxide removal. Environ. Sci. Pollut. Res. 25: 25702-25714.

Iuga, C., Ortíz, E. and Noreña, L. (2011). Interaction between volatile organic compounds and functional monomers in molecularly imprinted materials. Nanotech Conf. Expo. 3: 777-780.

Jiang, J., Ye, B. and Liu, J. (2019). Research on the peak of $\mathrm{CO}_{2}$ emissions in the developing world: Current progress and future prospect. Appl. Energy 235: 186203.

Jiang, Y., Bao, C., Liu, S., Liang, G., Lu, M., Lai, C., Shi, W. and $\mathrm{Ma}, \mathrm{S}$. (2018). Enhanced activity of $\mathrm{Nb}$ modified $\mathrm{CeO}_{2} / \mathrm{TiO}_{2}$ catalyst for the selective catalytic reduction of $\mathrm{NO}$ with $\mathrm{NH}_{3}$. Aerosol Air Qual. Res. 18: 2121-2130.

Kazmierczak-Razna, J., Gralak-Podemska, B., Nowicki, P. and Pietrzak, R. (2015). The use of microwave radiation for obtaining activated carbons from sawdust and their potential application in removal of $\mathrm{NO}_{2}$ and $\mathrm{H}_{2} \mathrm{~S}$. Chem. Eng. J. 269: 352-358.

Khan, F., Ghoshal, A. and Loss, J. (2000). Removal of volatile organic compounds from polluted air. Prev. Process Ind. 13: 527-545.

Kim, S., Bajaj, B., Byun, C.K., Kwon, S.J., Joh, H.I., Yi, K.B. and Lee, S. (2014). Preparation of flexible zinc oxide/carbon nanofiber webs for mid-temperature desulfurization. Appl. Surf. Sci. 320: 218-224.

Kong, Z., Niu, Z., He, L., Chen, Q., Zhou, L., Cheng, Y. and Guan, Q. (2018). In situ analysis of the adsorption behaviors of $\mathrm{CO}_{2}$ on the surface of MIL-91(Al). New J. Chem. 42: 16985.

Kooti, M., Pourreza, A. and Rashidi, A. (2018) Preparation of MIL-101-nanoporous carbon as a new type of nanoadsorbent for $\mathrm{H}_{2} \mathrm{~S}$ removal from gas stream. J. Nat. Gas Sci. Eng. 57: 331-338.

Lai, Q., Diao, Z., Kong, L., Adidharma, H. and Fan, M. (2018). Amine-impregnated silicic acid composite as an efficient adsorbent for $\mathrm{CO}_{2}$ capture. Appl. Energy 223: 293-301.

Lange, L.E. and Obendorf, S.K. (2015). Functionalization of cotton fiber by partial etherification and self-assembly of polyoxometalate encapsulated in $\mathrm{Cu}_{3}(\mathrm{BTC})_{2}$ metalorganic framework. ACS Appl. Mater. Interfaces 7: 3974-3980.

Lau, L.C., Nor, N.M., Lee, K.T. and Mohamed, A.R.J. (2015). Selection of better synthesis route of $\mathrm{CeO}_{2} / \mathrm{NaOH} / \mathrm{PSAC}$ for hydrogen sulphide removal from biogas. Environ. Chem. Eng. 3: 1522-1529.

Lee, S. and Park, S. (2015). A review on solid adsorbents for carbon dioxide capture. J. Ind. Eng. Chem. 23: 1-11.

Lee, S., Lee, T. and Kim, D. (2017). Adsorption of hydrogen sulfide from gas streams using the amorphous composite of $\alpha-\mathrm{FeOOH}$ and activated carbon powder. Ind. Eng. Chem. Res. 56: 3116-3122.

Li, D., Zhou, J., Wang, Y., Tian, Y., Wei, L., Zhang, Z., Qiao, Y. and Li, J. (2019). Effects of activation temperature on densities and volumetric $\mathrm{CO}_{2}$ adsorption performance of alkali-activated carbons. Fuel 238: 232 239.

Li, Y., Wang, L. J., Fan, H. L., Shangguan, J., Wang, H. and Mi, J. (2014). Removal of sulfur compounds by a copper-based metal organic framework under ambient conditions. Energy Fuels 29: 298-304.

Li, Y., Guo, Y., Zhu, T. and Ding, S. (2016). Adsorption and desorption of $\mathrm{SO}_{2}, \mathrm{NO}$ and chlorobenzene on activated carbon. J. Environ. Sci. 43: 128-135.

Li, Z., Liu, Y., Wang, H., Tsai, C., Yang, X., Xing, Y., Zhang, C., Xiao, P. and Webley, P. (2018). A numerical modelling study of $\mathrm{SO}_{2}$ adsorption on activated carbons with new rate equations. Chem. Eng. J. 353: 856-866.

Liao, T., Kou, L., Du, A., Chen, L., Cao, C. and Sun, Z. (2018). $\mathrm{H}_{2} \mathrm{~S}$ sensing and splitting on atom-functionalized carbon nanotubes: A theoretical study. Adv. Theory Simul. 1: 1700033.

Ling, Z., Wan, P., Yu, C., Xiao, N., Yang, J., Long, Y. and Qiu, J. (2015). One-pot to fabrication of calcium oxide/carbon foam composites for the adsorption of trace $\mathrm{SO}_{2}$. Chem. Eng. J. 259: 894-899.

Liu, C., Zhang, R., Wei, S, Wang, J., Liu, Y., Li, M. and Liu, R. (2015a). Selective removal of $\mathrm{H}_{2} \mathrm{~S}$ from biogas using a regenerable hybrid $\mathrm{TiO}_{2}$ /zeolite composite. Fuel 157: 183-190.

Liu, D., Zhou, W. and Wu, J. (2016). $\mathrm{CeO}_{2}-\mathrm{MnO}_{x} / \mathrm{ZSM}-5$ sorbents for $\mathrm{H} 2 \mathrm{~S}$ removal at high temperature. Chem. Eng. J. 284: 862-871.

Liu, F., Kuang, Y., Wang, S., Chen, S. and Fu, W. (2018b). Preparation and characterization of molecularly imprinted solid amine adsorbent for $\mathrm{CO}_{2}$ adsorption. New J. Chem. 42: 10016-10023.

Liu, G., Chernikova, V., Liu, Y., Zhang, K., Belmabkhout, Y., Shekhah, O., Zhang, C., Yi, S., Eddaoudi, M. and Koros, W.J. (2018a). Mixed matrix formulations with MOF molecular sieving for key energy-intensive separations. Nat. Mater. 17: 283-289.

Liu, J., Wei, Y., Li, P., Zhao, Y. and Zou, R. (2017). Selective $\mathrm{H}_{2} \mathrm{~S} / \mathrm{CO}_{2}$ separation by metal-organic frameworks based on chemical-physical adsorption. $J$. Phys. Chem. C. 121: 13249-13255.

Liu, X. and Wang, R. (2017a). An innovative approach to oxidative removal of hydrogen sulfide using the solution of peroxo heteropolyacid. Aerosol Air Qual. Res. 17: 1341-1346.

Liu, X. and Wang, R. (2017b). Effective removal of hydrogen sulfide using 4A molecular sieve zeolite synthesized from attapulgite. J. Hazard. Mater. 326: 157-164.

Liu, Y., Ghimire, P. and Jaroniec, M. (2019). Copper benzene-1, 3, 5-tricarboxylate (Cu-BTC) metal-organic framework (MOF) and porous carbon composites as efficient carbon dioxide adsorbents. J. Colloid Interface Sci. 535: 122-132.

Liu, Z., Wakihara, T., Oshima, K., Nishioka, D., Hotta, Y., Elangovan, S.P., Yanaba, Y., Yoshikawa, T., Chaikittisilp, W., Matsuo, T., Takewaki, T. and Okubo, T. (2015b). Widening synthesis bottlenecks: realization of ultrafast and continuous-flow synthesis of high-silica zeolite 
SSZ-13 for $\mathrm{NO}_{x}$ removal. Chem. Int. Ed. 54: 5683-5687. Louis, L., Olivier, S., Robert, D.K., Hamelers and H.V.M. (2018). Solvent-free $\mathrm{CO}_{2}$ capture using menbrance capcaitive deionization. Environ. Sci. Technol. 52: 9478-9485.

Maghsoudi, H., Soltanieh, M., Bozorgzadeh, H. and Mohamadalizadeh, A. (2013). Adsorption isotherms and ideal selectivities of hydrogen sulfide and carbon dioxide over methane for the Si-CHA zeolite: Comparison of carbon dioxide and methane adsorption with the allsilica DD3R zeolite. Adsorption 19: 1045-1053.

Marszewska, J. and Jaroniec, M. (2017). Tailoring porosity in carbon spheres for fast carbon dioxide adsorption. $J$. Colloid Interface Sci. 487: 162-174.

Matsuguchi, M. and Uno, T. (2006). Molecular imprinting strategy for solvent molecules and its application for QCM-based VOC vapor sensing. Sens. Actuators, B 113: 94-99.

Mendt, M., Barth, B., Hartmann, M. and Pöppl, A. (2017). Low-temperature binding of NO adsorbed on MIL-100 (Al)-A case study for the application of high resolution pulsed EPR methods and DFT calculations. J. Chem. Phys. 147: 224701.

Mo, J., Zhang, Y., Xu, Q., Lamson, J. and Zhao, R. (2009). Photocatalytic purification of volatile organic compounds in indoor air: A literature review. Atmos. Environ. 43: 2229-2246.

Mon, M., Tiburcio, E., Ferrando-Soria, J., San Millán, R. G., Navarro, J.A., Armentano, D. and Pardo, E. (2018). A post-synthetic approach triggers selective and reversible sulphur dioxide adsorption on a metal-organic framework. Chem. Commun. 54: 9063-9066.

Mounfield III, W.P., Han, C., Pang, S.H., Tumuluri, U., Jiao, Y., Bhattacharyya, S., Dutzer, M., Nair, S., Wu, Z., Lively, R., Sholl, D.S. and Walton, K. (2016). Synergistic effects of water and $\mathrm{SO}_{2}$ on degradation of MIL-125 in the presence of acid gases. J. Phys. Chem. C 120: 27230-27240.

Nabavi, S., Vladisavljević, G., Zhu, Y. and Manović, V. (2017). Synthesis of size-tunable $\mathrm{CO}_{2}$-philic imprinted polymeric particles (MIPs) for low-pressure $\mathrm{CO}_{2}$ capture using oil-in-oil suspension polymerization. Environ. Sci. Technol. 51: 11476-11483.

Nam, H., Wang, S. and Jeong, H. R. (2018). TMA and $\mathrm{H}_{2} \mathrm{~S}$ gas removals using metal loaded on rice husk activated carbon for indoor air purification. Fuel 213: 186-194.

Nguyen, H., Tran, Y., Nguyen, H., Nguyen, T., Felipe Gańdara, and Nguyen, P. (2018). A series of metalorganic frameworks for selective $\mathrm{CO}_{2}$ capture and catalytic oxidative carboxylation of olefins. Inorg. Chem. 21: 13772-13782.

Nickerl, G., Leistner, M., Helten, S., Bon, V., Senkovska, I. and Kaskel, S. (2014). Integration of accessible secondary metal sites into MOFs for $\mathrm{H}_{2} \mathrm{~S}$ removal. Inorg. Chem. Front. 1: 325-330.

Nowicki, P., Skibiszewska, P. and Pietrzak, R. (2014). Hydrogen sulphide removal on carbonaceous adsorbents prepared from coffee industry waste materials. Chem. Eng. J. 248: 208-215.
Ogungbenro, A., Quang, D., Al-Ali, K., Vega, L. and AbuZahra, M. (2018). Physical synthesis and characterization of activated carbon from date seeds for $\mathrm{CO}_{2}$ capture. $J$. Environ. Chem. Eng. 6: 4245-4252.

Osaka, Y., Kito, T., Kobayashi, N., Kurahara, S., Huang, H., Yuan, H. and He, Z. (2015). Removal of sulfur dioxide from diesel exhaust gases by using dry desulfurization $\mathrm{MnO}_{2}$ filter. Sep. Purif. Technol. 150: 80-85.

OSHA (2015). General safety and health. 2015. http://www.osha.gov/SLTC/etools/oilandgas/general_sa fety /general safety.html.

Pai, K.N., Baboolal, J.D., Sharp, D.A. and Rajendran, A. (2019). Evaluation of diamine-appended metal-organic frameworks for post-combustion $\mathrm{CO}_{2}$ capture by vacuum swing adsorption. Sep. Purif. Technol. 211: 540-550.

Pan, H., Guo, Y. and Bi, H.T. (2015). $\mathrm{NO}_{x}$ adsorption and reduction with $\mathrm{C}_{3} \mathrm{H}_{6}$ over Fe/zeolite catalysts: Effect of catalyst support. Chem. Eng. J. 280: 66-73.

Park, E., Seo, H. and Kim, Y. (2017). Influence of humidity on the removal of volatile organic compounds using solid surfaces. Catal. Today 295: 3-13.

Peng, S.Y., Wang, J.H. and Ma, L.P. (2014). Sulfur dioxide was carried out by activated carbon adsorption in combination with microwave desorption in scene. Adv. Mater. Res. 1049-1050: 44-49.

Quijano, G., Couvert, A., Amrane, A., Darracq, G., Couriol, C., Cloirec, P., Paquin, L. and Carrié, D. (2011). Potential of ionic liquids for VOC adsorption and biodegradation in multiphase systems. Chem. Eng. Sci. 66: 2707-2712.

Ranjbar, M. and Taher, M.A. (2016). Preparation of Nimetal organic framework-74 nanospheres by hydrothermal method for $\mathrm{SO}_{2}$ gas adsorption. J. Porous Mater. 23: 1249-1254.

Rayer, A., Mobley, P., Soukri, M., Gohndrone, T., Tanthana, J., Zhou, J. and Lail, M. (2018). Adsorption rates of carbon dioxide in amines in hydrophilic and hydrophobic solvents. Chem. Eng. J. 348: 514-525.

Rezakazemi, M., Darabi, M., Soroush, E. and Mesbah, M. (2019) $\mathrm{CO}_{2}$ adsorptionenhancement by water-based nanofluids of CNT and $\mathrm{SiO}_{2}$ using hollow-fiber membrane contactor. Sep. Purif. Technol. 210: 920-926.

Saeedirad, R., Ganjali, S.T., Bazmi, M. and Rashidi, A. (2018). Effective mesoporous silica-ZIF-8 nano-adsorbents for adsorptive desulfurization of gas stream. J. Taiwan Inst. Chem. Eng. 82: 10-22.

Sager, U., Däuber, E., Bathen, D., Asbach, C., Schmidt, F., Tseng, J.C., Pommerin, A., Weidenthaler, C. and Schmidt, W. (2016). Influence of the degree of infiltration of modified activated carbons with $\mathrm{CuO} / \mathrm{ZnO}$ on the separation of $\mathrm{NO}_{2}$ at ambient temperatures. Adsorpt. Sci. Technol. 34: 307-319.

Sánchez-González, E., Mileo, P.G., Sagastuy-Breña, M., Álvarez, J.R., Reynolds, J.E., Villarreal, A., GutiérrezAlejandre, A., Ramírez, J., Balmaseda, J., GonzálezZamora, E., Maurin, G., Humphrey, S. and Ibarra, I. (2018). Highly reversible sorption of $\mathrm{H}_{2} \mathrm{~S}$ and $\mathrm{CO}_{2}$ by an environmentally friendly Mg-based MOF. J. Mater. Chem. 6: 16900-16909.

Santiago, R., Lemus, J., Moreno, D., Moya, C., Larriba, 
M., Alonso-Morales, N., Gilarranz, M.A., Rodríguez, J.J. and Palomar, J. (2018). From kinetics to equilibrium control in $\mathrm{CO}_{2}$ capture columns using Encapsulated Ionic Liquids (ENILs). Chem. Eng. J. 348: 661-668.

Saputro, A.G., Agusta, M.K., Yuliarto, B., Dipojono, H.K., Rusydi, F. and Maezono, R. (2017). Selectivity of CO and NO adsorption on $\mathrm{ZnO}$ (0002) surfaces: A DFT investigation. Appl. Surf. Sci. 410: 373-382.

Savage, M., Cheng, Y., Easun, T.L., Eyley, J.E., Argent, S.P., Warren, S.P., Warren, M.R., Lewis, W., Murray, C., Tang, C., Frogley, M., Cinque, G., Sun, J., Rudic, S., Murden, R., Benham, M., Fitch, A., Blake, A., RamirezCuesta, A., Yang, S. and Schroder, M. (2016). Selective adsorption of sulfur dioxide in a robust metal-organic framework material. Adv. Mater. 28: 8705-8711.

Severa, G., Bethune, K., Rocheleau, R. and Higgins, S. (2015). $\mathrm{SO}_{2}$ sorption by activated carbon supported ionic liquids under simulated atmospheric conditions. Chem. Eng. J. 265: 249-258.

Sevilla, M. and Fuertes, A. (2012). $\mathrm{CO}_{2}$ adsorption by activated templated carbons. J. Colloid Interface Sci. 366: $147-154$.

Shah, M.S., Tsapatsis, M. and Siepmann, J.I. (2015). Monte carlo simulations probing the adsorptive separation of hydrogen sulfide/methane mixtures using all-silica zeolites. Langmuir 31: 12268-12278.

Shalini, S., Nandi, S., Justin, A., Maity, R. and Vaidhyanathan, R. (2018). Potential of ultramicroporous metal-organic frameworks in $\mathrm{CO}_{2}$ clean-up. Chem. Commun. 54: 13472.

Shao, L., Sang, Y., Huang, J. and Liu, Y. (2018a). Triazinebased hyper-cross-linked polymers with inorganicorganic hybrid framework derived porous carbons for $\mathrm{CO}_{2}$ capture. Chem. Eng. J. 353: 1-14.

Shao, J., Zhang, J., Zhang, X., Feng, Y., Zhang, H., Zhang, S. and Chen, H. (2018b). Enhance $\mathrm{SO}_{2}$ adsorption performance of biochar modified by $\mathrm{CO}_{2}$ activation and amine impregnation. Fuel 224: 138-146.

Shin, M., Shin, Y. and Shin, J. (2018). Cholesterol recognition system by molecular imprinting on selfassembled monolayer. Colloids Surf. A. 559: 365-371.

Sidek, M., Cheah, Y., Zulkefli, N., Yusuf, N., Isahak, W. and Masdar, M. (2019). Effect of impregnated activated carbon on carbon dioxide adsorption performance for biohydrogen purification. Mater. Res. Express 6: 015510.

Sigot, L., Ducom, G. and Germain, P. (2016a). Adsorption of hydrogen sulfide $\left(\mathrm{H}_{2} \mathrm{~S}\right)$ on zeolite $(\mathrm{Z})$ : Retention mechanism. Chem. Eng. J. 287: 47-53.

Sigot, L., Obis, M.F., Benbelkacem, H., Germain, P. and Ducom, G. (2016b). Comparing the performance of a $13 \mathrm{X}$ zeolite and an impregnated activated carbon for $\mathrm{H}_{2} \mathrm{~S}$ removal from biogas to fuel an SOFC: Influence of water. Int. J. Hydrogen Energy 41: 18533-18541.

Silva, C., Howarth, A., Rimoldi, M., Islamoglu, T., Rinaldi, A. and Hupp, J. (2018). Phosphonates meet metalorganic frameworks: Towards $\mathrm{CO}_{2}$ adsorption. Isr. J. Chem. 58: 1164-1170.

Skarlis, S.A., Berthout, D., Nicolle, A., Dujardin, C. and Granger, P. (2014). Combined IR spectroscopy and kinetic modeling of $\mathrm{NO}_{x}$ storage and $\mathrm{NO}$ oxidation on Fe-BEA SCR catalysts. Appl. Catal. B 148: 446-465.

Song, J., Luo, Z., Britt, D.K., Furukawa, H., Yaghi, O.M., Hardcastle, K.I. and Hill, C.L. (2011). A multiunit catalyst with synergistic stability and reactivity: A polyoxometalate-metal organic framework for aerobic decontamination. J. Am. Chem. Soc. 133: 16839-16846.

Song, X.D., Wang, S., Hao, C. and Qiu, J.S. (2014). Investigation of $\mathrm{SO}_{2}$ gas adsorption in metal-organic frameworks by molecular simulation. Inorg. Chem. Commun. 46: 277-281.

Song, Z., Wei, Z., Wang, B., Luo, Z., Xu, S., Zhang, W., Yu, H., Li, M., Huang, Z., Zang, J., Yi, F. and Liu, H. (2016). Sensitive room-temperature $\mathrm{H}_{2} \mathrm{~S}$ gas sensors employing $\mathrm{SnO}_{2}$ quantum wire/reduced graphene oxide nanocomposites. Chem. Mater. 28: 1205-1212.

Sun, F., Gao, J., Liu, X., Yang, Y. and Wu, S. (2016). Controllable nitrogen introduction into porous carbon with porosity retaining for investigating nitrogen doping effect on $\mathrm{SO}_{2}$ adsorption. Chem. Eng. J. 290: 116-124.

Sun, T., Shen, Y. and Jia, J. (2014a). Gas cleaning and hydrogen sulfide removal for COREX coal gas by sorption enhanced catalytic oxidation over recyclable activated carbon desulfurizer. Environ. Sci. Technol. 48: 2263-2272.

Sun, W., Lin, L.C., Peng, X. and Smit, B. (2014b). Computational screening of porous metal-organic frameworks and zeolites for the removal of $\mathrm{SO}_{2}$ and $\mathrm{NO}_{x}$ from flue gases. AIChE J. 60: 2314-2323.

Sun, X., Ruan, H., Song, X., Sun, L., Li, K., Ning, P. and Wang, C. (2018). Research into the reaction process and the effect of reaction conditions on the simultaneous removal of $\mathrm{H}_{2} \mathrm{~S}, \mathrm{COS}$ and $\mathrm{CS}_{2}$ at low temperature. $R S C$ $A d v$. 8: 6996-7004.

Tailor, R., Abboud, M. and Sayari, A. (2014). Supported polytertiary amines: Highly efficient and selective $\mathrm{SO}_{2}$ adsorbents. Environ. Sci. Technol. 48: 2025-2034.

Tailor, R. and Sayari, A. (2016). Grafted propyldiethanolamine for selective removal of $\mathrm{SO}_{2}$ in the presence of $\mathrm{CO}_{2}$. Chem. Eng. J. 289: 142-149.

Tehrani, N., Alivand, M., Maklavany, Da., Rashidi, A., Samipoorgiri, M., Seif, A. and Yousefian, Z. (2019) Novel asphaltene-derived nanoporous carbon with N-Srich micro- $\mathrm{T}$ mesoporous structure for superior gas adsorption: Experimental and DFT study. Chem. Eng. J. 358: 1126-1138.

Tobiesen, F., Haugen, G. and Hartono, A. (2018). A systematic procedure for process energy evaluation for post combustion $\mathrm{CO}_{2}$ capture: case study of two novel strong bicarbonate-forming solvents. Appl. Energy 211: 161-173.

Tomadakis, M.M., Heck, H.H., Jubran, M.E. and AlHarthi, K. (2011). Pressure-swing adsorption separation of $\mathrm{H}_{2} \mathrm{~S}$ from $\mathrm{CO}_{2}$ with molecular sieves $4 \mathrm{~A}, 5 \mathrm{~A}$, and 13X. Sep. Sci. Technol. 46: 428-433.

Tran, H.L., Kuo, M.S., Yang, W.D. and Huang, Y.C. (2016). Hydrogen sulfide adsorption by thermally treated cobalt (II)-exchanged $\mathrm{NaX}$ zeolite. Adsorpt. Sci. Technol. 34: $275-286$. 
Wang, F., Yi, H. and Tang, X. (2017a). Removal of NO using a dielectric barrier discharge reactor in a cycled adsorption-desorption and decomposition system. Arabian J. Sci. Eng. 42: 1463-1474.

Wang, H., Wang, T., Han, L., Tang, M., Zhong, J., Huang, W. and Chen, R. (2016) VOC adsorption and desorption behavior of hydrophobic, functionalized SBA-15. J. Mater. Res. 31: 516-525.

Wang, M., Liu, H., Huang, Z.H. and Kang, F. (2014) Activated carbon fibers loaded with $\mathrm{MnO}_{2}$ for removing NO at room temperature. Chem. Eng. J. 256: 101-106.

Wang, W., Ma, X., Grimes, S., Cai, H. and Zhang, M. (2017b). Study on the absorbability, regeneration characteristics and thermal stability of ionic liquids for VOCs removal. Chem. Eng. J. 328: 353-359.

Wang, X., Li, H., Liu, H., Hou, X. (2011). AS-synthesized mesoporous silica MSU-1 modified with tetraethylenepentamine for $\mathrm{CO}_{2}$ adsorption. Microporous Mesoporous Mater. 142: 564-569.

Wang, Y., Wang, J., Ma, C., Qiao, W. and Ling, L. (2019). Fabrication of hierarchical carbon nanosheet-based networks for physical and chemical adsorption of $\mathrm{CO}_{2}$. J. Colloid Interface Sci. 534: 72-80.

Wawrzyńczak, D., Majchrzak-Kucęba, I., Srokosz, K., Kozak, M., Nowak, W., Zdeb, J., Smółka, W. and Zajchowski, A. (2019). The pilot dual-reflux vacuum pressure swing adsorption unit for $\mathrm{CO}_{2}$ capture from flue gas. Sep. Purif. Technol. 209: 560-570.

Wei, L., Gao, Z. and Wang, Y. (2017). Integrated twostage adsorption for selective removal of $\mathrm{CO}_{2}$ and $\mathrm{SO}_{2}$ by amine-functionalized SBA-15. Asia-Pacific J. Chem. Eng. 12: 660-670.

Wu, M., Chang, B., Lim, T.T., Oh, W.D., Lei, J. and Mi, J. (2018). High-sulfur capacity and regenerable Zn-based sorbents derived from layered double hydroxide for hot coal gas desulfurization. J. Hazard. Mater. 360: 391-401.

Xia, L., Cui, Q., Suo, X., Li, Y., Cui, X., Yang, Q., Xu, J., Yang, Y. and Xing, H. (2018). Efficient, selective, and reversible $\mathrm{SO}_{2}$ capture with highly crosslinked ionic microgels via a selective swelling mechanism. $A d v$. Funct. Mater. 28: 1704292.

Xie, W., Yu, M. and Wang, R. (2017). $\mathrm{CO}_{2}$ capture behaviors of amine-modified resorcinol-based carbon aerogels adsorbents. Aerosol Air Qual. Res. 17: 27152725.

Xu, X., Cao, X., Zhao, L. and Sun, T. (2014). Comparison of sewage sludge-and pig manure-derived biochars for hydrogen sulfide removal. Chemosphere 111: 296-303.

Xu, Z., Deng, P., Li, J., Tang, S. and Cui, Y. (2019). Modification of mesoporous silica with molecular imprinting technology: A facile strategy for achieving rapid and specific adsorption. Mater. Sci. Eng. C 94: 684-693.

Yang, N. and Wang, R. (2015). Sustainable technologies for the reclamation of greenhouse gas $\mathrm{CO}_{2}$. J. Clean. Prod. 103: 784-792.

Yi, H., Zuo, Y., Liu, H., Tang, X. Zhao, S., Wang, Z., Gao, F. and Zhang, B. (2014). Simultaneous removal of $\mathrm{SO}_{2}$, $\mathrm{NO}$, and $\mathrm{CO}_{2}$ on metal-modified coconut shell activated carbon. Water, Air, Soil Pollut. 225: 1965.

Ying, W. and Nan, L. (2010). Molecular imprinting technology and its application. Chem. Ind. Eng. Prog. 29: 2315-2323.

Yu, G., Dai, C., Gao, H., Zhu, R., Du, X. and Lei, Z. (2018a). Capturing condensable gases with ionic liquids. Ind. Eng. Chem. Res. 57: 12202-12214.

Yu, Q., Gao, Y., Tang, X., Yi, H., Zhang, R. Zhao, S., Gao, F. and Zhou, Y. (2018b). Removal of NO from flue gas over HZSM-5 by a cycling adsorption-plasma process. Catal. Commun. 110: 18-22.

Yu, Z., Wang, X., Song, X., Liu, Y. and Qiu, J. (2015). Molten salt synthesis of nitrogen-doped porous carbons for hydrogen sulfide adsorptive removal. Carbon 95: 852-860.

Yun, S., Lee, H., Lee, W.E. and Park, H.S. (2016). Multiscale textured, ultralight graphene monoliths for enhanced $\mathrm{CO}_{2}$ and $\mathrm{SO}_{2}$ adsorption capacity. Fuel 174: $36-42$.

Zha, Y., Shen, Y., Bai, L., Hao, R. and Dong, L. (2012). Synthesis and $\mathrm{CO}_{2}$ adsorption properties of molecularly imprinted adsorbents. Environ. Sci. Technol. 46: 17891795.

Zhang, G., Sun, Y., Xu, Y. and Zhang, R. (2018). Catalytic performance of $\mathrm{N}$-doped activated carbon supported cobalt catalyst for carbon dioxide reforming of methane to synthesis gas. J. Taiwan Inst. Chem. Eng. 93: 234244.

Zhang, H., Cen, W., Liu, J., Guo, J., Yin, H. and Ning, P. (2015). Adsorption and oxidation of $\mathrm{SO}_{2}$ by graphene oxides: A van der Waals density functional theory study. Appl. Surf. Sci. 324: 61-67.

Zhang, Y., Yuan, S., Feng, X., Li, H., Zhou, J. and Wang, B. (2016). Preparation of nanofibrous metal-organic framework filters for efficient air pollution control. $J$. Am. Chem. Soc. 138: 5785-5788.

Zhao, Q., Wu, F., Men, Y., Fang, X., Zhao, J., Xiao, P., Webley, P. and Grande, C. (2019). $\mathrm{CO}_{2}$ capture using a novel hybrid monolith (H-ZSM5/activated carbon) as adsorbent by combined vacuum and electric swing adsorption (VESA). Chem. Eng. J. 358: 707-717.

Zhao, Y., Shen, Y., Ma, G. and Hao, R. (2014). Adsorption separation of carbon dioxide from flue gas by a molecularly imprinted adsorbent. Environ. Sci. Technol. 48: 1601-1608.

Zhao, Y., Liu, X. and Han, Y. (2015). Microporous carbonaceous adsorbents for $\mathrm{CO}_{2}$ separation via selective adsorption. RSC Adv. 5: 30310-30330.

Zhao, Y., Wang, H. and Wang, T. (2016). Adsorption of NO from flue gas by molecularly imprinted adsorbents. Chem. Eng. J. 306: 832-839.

Zhao, Y., Wang, H. and Wang, T. (2017). Preparation of molecularly imprinted adsorbents and NO adsorption property. Funct. Mater. Lett. 10: 1650070.

Zhou, J., Wang, B., Nie, L., Lu, J., Hao, Y. and Xu, R. (2018a). Experimental study on emission of VOCs from tanker using hollow fiber membrane adsorption method with different absorbents. IOP Conf. Ser.: Mater. Sci. Eng. 292: 012113. 
Zhou, L., Niu, Z., Jin, X., Tang, L. and Zhu, L. (2018b). Effect of lithium doping on the structures and $\mathrm{CO}_{2}$ adsorption properties of metal-organic frameworks HKUST-1. Chem. Select. 3: 12865-12870.
Received for review, April 20, 2019

Revised, August 15, 2019

Accepted, August 16, 2019 